PONTIFICIA UNIVERSIDAD CATOLICA DEL PERU

FACULTAD DE DERECHO $Y$ CIENCIAS POLITICAS

El Control de las Sociedades Anónimas

EN LA

LEGISLACION DE CHILE, ESPAÑA, SUIZA Y EL PERU

POR EL

Doctor LUIS ECHECOPAR GARCIA,

Catedrático Titular de Derecho Civil

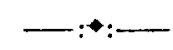

LIMA-PERU

1955 



\title{
El control de las Sociedades Anónimas en la Legislación de Chile, España, Suiza y el Perú
}

\author{
por el Doctor LUIS ECHECOPAR GARCIA, \\ Catedrático Titular de Derecho Civil en la Universidad Católica.
}

\section{CAPITULO I}

\section{Generalidades}

\section{1.-Introducción}

El estudio comparativo de la legislación sobre sociedades anónimas que rige en Chile, España, Suiza y el Perú, reviste singular interés, por cuanto del mismo pueden desprenderse conclusiones fundamentales para la futura reglamentación de tan importante institución en el país.

La legislación Suiza se destaca por su reconocido equilibrio y perfección: la española, por el acierto de sus disposiciones, que la hacen un verdadero modelo de lo que debe ser una ley de esta clase; la chilena, por la excesiva intervención del Estado en la creación, funcionamiento y vigilancia de las sociedades anónimas; $y$, la nuestra, por la excepcional libertad $y$ falta de reglamentación del instituto.

Existen, naturalmente, otras legislaciones dignas de examen, como la alemana, la argentina, la brasilera, la trancesa, la italiana y las de tipo anglo-sajón, pero nos es forzoso dejar su revisión para otra oportunidad, pues sería imposible comprender tan variados casos en unas pocas páginas.

No pretendemos hacer un análisis completo de las sociedades anónimas, sino, más bien, despertar el interés por el estudio de las normas que las rigen en diversos países, con miras a contribuir en alguna forma al conocimiento de los mejores sistemas y al perfeccionamiento de la legislación de nuestra patria. 


\section{2.-Posición jurídica}

Dos posiciones jurídicas completamente diferentes podemos observar en las legislaciones materia de nuestro estudio.

En tanto que Suiza abraza la tesis civilista, al incluir las reglas sobre sociedades anónimas en el Código de las Obligaciones, que involucra en un sólo cuerpo tanto los actos civiles como los mercantiles; Chile, España y el Perú adoptan la tendencia mercantilista, al regular el primero y el último las sociedades anónimas en sus respectivos Códigos de comercio, y España en la ley especial de 27 de Julio de 1951, que da a esta clase de entidades el carácter mercantil (art. 3), y obliga a convertir también en mercantiles a las sociedades anónimas de origen civil ( $2^{q}$ disposición transitoria).

Esta distinción que podría ser de simple método tiene, sin embargo, trascendencia especial, pues, mientras que el Código Suizo declara expresamente (art. 620), que las sociedades anónimas pueden ser fundadas para perseguir un fin que no sea de naturaleza económica, las otras tres legislaciones no dicen nada sobre el particular y hacen pensar, que, aún cuando las sociedades anónimas puedan en los respectivos países practicar actos civiles, deben por lo menos, tener un fin lucrativo mercantil, o de naturaleza económica.

Dan lugar a esta interpretación el segundo párrafo del art. $3^{\circ}$ de la ley española cuando dice que la sociedad anónima no podrá téner por objeto la representación de intereses colectivos, profesionales o económicos atribuíbles a otras entidades por la ley con carácter exclusivo; y el artículo 124 del Código de Comercio Peruano según el cual el fin del contrato de compañía es obtener lucro. En cuanto a Chile, la organización general de las sociedades anónimas sólo con fin económico y aprobación del Gobierno justifica esta tesis.

Se presentará así entre nosotros al legislar sobre las sociedades anónimas, el doble problema de saber:

A) Si debe adoptarse la tendencia mercantilista o la civilista; y

B) Si podrá autorizarse o no la constitución de sociedades anónimas con fin no económico.

Con respecto al primer punto consideramos que, aún cuando no haya diferencia substancial entre los actos civiles y los mercantiles (tanto lucra el que produce algodón como el que comercia con el producto, el cue compra un inmueble para alquilarlo y después lo vende, como el que haca de la compra-venta de inmuebles su profesión habitual; $y$ tanto debe llevar hoy libros de contabilidad el civil como el comerciante para los efectos de los impuestos), no es posible que la legislación peruana se afilie netamente, a la tendencia civilista, desde que la separación entre la legislación civil y la comercial está ya definitivamente producida y sólo reformado el actual Código Civil sería posible llegar a ese fin, lo que no sería prudente ni acon- 
sejable teniendo en cuenta los escasos años de vigencia del nuevo Código, cuyo conocimiento recién va asentándose.

Naturalmente, al dar un nuevo Código de Comercio podría hacerse en forma tal que se reconozca la unidad fundamental que en nuestro concepto existe entre el Derecho Civil y el Mercantil.

En cuanto al segundo punto, estamos enteramente de acuerdo con el Mensaje de la Comisión Reformadora del Código Suizo de las Obligacianes, cuando decía que " $y \propto$ no parece necesario estatuir hoy, expresamente, "que una sociedad anónima puede ser constituída con un fin distinto del "económico".

Hemos visto entre nosotros crearse sociedades inmobiliarias para que un Colegio o un Club pudiera contar con un local apropiado; y no encontramos razón para que se restrinja en este aspecto la capacidad de las sociedades anónimas, salvo la normal prohibición de ejecutar actos contra el orden público, la moral o las buenas costumbres.

No se comprende, por otra parte, por qué razón una entidad benéfica, humanitaria o artística, no pueda revestir la forma de sociedad anónima, si sus fundadores quieren adoptarla no sólo para limitar su responsabilidad, sino para organizar su administración, ingreso y egreso de socios, liquidación y control, etc., etc.

La realidad es que aún las entidades más apartadas del comercio o del lucro requieren por lo general de bases económicas para subsistir y que, por lo mismo, deben estar facultadas para organizar este aspecto de sus actividades en foma adecuada.

Así, por ejemplo, quienes fundan una galería de pinturas para fo. mentar el arte, tienen que dotarla de fondos y no siempre desean enajenar sus derechos a una Fundación; puede ser que quieran reservarse la posibilidad de recuperar su inversión en caso de liquidación de la galería, - que deseen trasmitir $\alpha$ sus herederos 0 a terceros este derecho hacién. dolo representar por acciones.

\section{3.-Orientación social}

Tanto la legislación peruana como la chilena de sociedades anónimas, por razón de la época en que fueron expedidas, no hacen referencia al problema social.

En cambio, la ley suiza ya revela una tendenca humanitaria definida al estatuir que, en cuanto al fondo de reserva no sobrepase la mitad del capital social, no puede ser empleado sino en cubrir las pérdidas o en tomar las medidas que permitan a la empresa mantenerse en tiempo de explotaciones deficitarias $\mathrm{y}$ evitar la desocupación o atenuar sus consecuencias.

Del mismo modo, en España, aún cuando en la exposición de motivos de la ley se expresa que no intenta abordar los problemas de tipo social porque desea concretarse solamente a la reforma mercantil de este tipo de entidades, pues debe distinguirse entre la empresa como organización económica caracterizada por la comunidad del trabajo y la sociedad 
mercantil como persona jurídica titular de la empresa, sin embargo, en más de un artículo revela la preocupación social que inspira a los gobernantes de la Madre Patria.

Ella se refleja especialmente en los artículos 151 y 171 , el primero de los cuales establece que el Gobiemo, cuando lo juzgue conveniente para la economía nacional o interés social podrá acordar la continuación de una sociedad cuya disolución se haya resuelto por los accionistas, previa compensación, por supuesto; y el segundo de los cuales, determina que cuando el capital que haya sido objeto de liquidación y división al término de una sociedad anónima sea cucintioso o estén repartidas entre gran número de tenedores las obligaciones y acciones, podrá el Gócierno designar una persona que se encargue de intervenir y presidir la liquidación y de velar por el cumplimiento de las leyes $y$ del estado social.

\section{4.-Sistema y redacción}

El método de los cuatro cuerpos legales que examinamos, es completamente diferente.

Tanto la legislación suiza como la española y la chilena son exten. sas. La primera cuenta con 144 artículos relativos a sociedades anónimas, mós 63 disposiciones que se refieren al Registro de Comercio, $\alpha$ las razones de comercio, a la contabilidad comercial y a los papeles valores; la española llega a 171 artículos más 21 disposiciones transitorics; y la chilena consta de 56 artículos en el Código de Comercio; de varias leyes especiales $\mathrm{Y}$ de un reglamento con 50 artículos.

En cambio, nuestro Código solo contiene, en total, 8 crtículos específicos sobre las sociedades anónimas, 16 más comunes a éstas con las scciedades en comandita y unos pocos más relativos a la liquidación de sociedades.

La legislación Suiza y la Española cuidan del detalle y regulan todos los casos principales, evitando, casi totalmente, las referencias a otras leyes; la chilena no es tan minuciosa y se resiente por estar contenida en varios cuerpos legislativos, pero también se pronuncia sobre los asuntos más notables. En cambio, el Código Peruano es tan lacónico y de carácter tan genérico, que deja prácticamente a la escritura social y a los esta. tutos la resolución de las más importantes cuestiones.

Todas son claras; pero es evidente que, donde ha habido mayor previsión legislativa, es menor la posibilidad de conflictos.

Pero, lo que más debemos destacar, es que mientras las leyes de Chile, España y Suiza siguen la tendencia mundial de reglamentar concienzudamente las sociedades anónimas, el Perú persiste en un sirteria de desorbitada libertad, ésto es. en el "laissez faire" más absoluto.

Siendo nuestro Código de Comercio copia literal del español de 1885, creemos que le son aplicables los siguientes párrafos de la exposición de motivos de la ley española de 17 de Julio de 1951 que deroga la parte pertinente del código peninsular: 
"Desde hace un siglo los legisladores mercantiles y los hombres de "empresa coinciden al pensar que la elección por los fundadores "de una sociedad de la forma onónima lleva consigo la necesidad "de someterse a ciertos esquemas legales insustituibles por el arbitrio “individual. Así lo exige el privilegio de la limitación de la responsa"bilidad del accionista y la conveniencia de proteger la ingente masa "del ahorro que se canaliza hacia la inversión en forma de acciones "de sociedad. Y si es justo reconocer que, a causa del ambiente de "honestidad en que generalmente se desenvuelve la vida de los "negocios en España, esta insólita libertad de que gozaron hasta hoy "los fundadores y las mayorías de accionistas no ha producido gra"ves escándalos, tampoco sería justo ni razonable empeñarse en "mantenex, frente al Derecho universal de la sociedad por acciones, "un régimen de excepción que sólo puede producir frutos de insegu"ridad y de incertidumbre en las relaciones jurídicas nacidas en "torno a este tipo de la sociedad. La ausencia de una ley regula"dora de la sociedad anónima sólo podría demostrarse justificando "que la economía española es antagónica o radicalmente diversa a "la de los países en los que rigen leyes de esta clase. Esto nadie "podría demostrarlo, y en cambio, todos estamos convencidos de "que la sociedad por acciones, por ser la pieza maestra de la eco"nomía industrial moderna, debe ser sometida a una ley que, sin "atentar a la libre iniciativa privada del empresario, la encauce por "normas jurídicas inspiradas en la mayor garantía de accionistas y "acreedores, y en definitiva, en el bien común, al que, por principio, "ha de subordinarse el interés privado por respetable que sea".

\section{5.-Tỉpos de control}

Si bien en Chile, España y Suiza se reglamenta, como queda dicho, las sociedades anónimas con el fin de asegurar la seriedad y normal desenvolvimiento de estas instituciones, sus sistemas difieren substancialmente entre si y, por supuesto, con el peruano en que no hay reglamentación.

Chile conserva el sistema inherente $a$ las primitivas sociedades anónimas, de control directo por el Estado.

Allí las sociedades anónimas sólo existen en virtud de un decreto del Presidente de la República que las auiorice (art. 427 del Código de Comer. cio); el mismo Presidente puede nombrar un comisario que vigile las operaciones de los administradores y le dé cuenta de la inejecución o infracción de los Estatutos (art. 436 del Código de Comercio); y está facultado para revocar la licencia de las sociedades anónimas por la inobservancia o violación de los estatutos, (art. 437 del Código de Comercio). Para modít ficar los Estatutos, prorrogar las sociedades y para disolverlas antes del término estipulado o fuera de los casos previstos por la ley, se necesita su consentimiento (art. 427 del Código de Comercio in fine); $\mathrm{Y}$, en todo tiempo las sociedades anónimas están sujetas a la vigilancia de la Superintendencia de Compañías de Seguros, de Sociedades Anónimas y Bolsas de Comer- 
cio, dependencias del Ministerio de Hacienda encargada de fiscalizarlas desde la escritura de constitución hasta su término (art. 438 del Código de Comercio y Decreto con fuerza de ley $N^{\circ} 251$ de 20 de Mayo de 1931).

En Chile, la Superintendencia tiene las siguientes facultades y atribuciones (art. 83 del Decreto No 251):

A) Informar al Presidente de la República, teniendo a la vista todos los documentos que acrediten haberse dado cumplimiento a las disposiciones vigentes sobre las presentaciones en que se solicite la autorización de existencia, la aprobación o modificación de los estatutos, declaración de legalmente instalada o disolución an. ticipada de una Sociedad Anónima;

Bi Fiscalizar las operaciones de las Sociedades, pudiendo revisar los libros de contabilidad y documentación en general, hacer arqueos, pedir la ejecución y presentación de balances en las fechas que estime conveniente $y$ en general, solicitar todos los datos y antecedentes que le permitan imponerse del desarrollo de los negocios sociales;

C) Velar por el cumplimiento de la ley, y por el de los estatutos sociales, debiendo representar al Directorio y Gerente las infrac ciones o actos que $\alpha$ su juicio sean perjudiciales para la Sociedad.

D) Citar a Juntas Generales Extraordinarias de Accionistas, cuando requerido el Directorio al efecto se hubiere negado a hacerlo. Podrá asimismo, y ante la negativa del Directorio, suspender la citación a Junta de Accionjstas y la Junta misma, cuando fueren contrarias a la ley o a los estatutos;

E) Hacerse representar en toda Junta de Accionistas, cuando lo estime prudente;

F) Comprobar la exactitud e inversión de los capitales y fondos $y$ vigilor que se constituya el fondo de reserva legal;

G) Comprobar, cuando lo estime conveniente, la exactitud de los informes y la valorización de todo aporte que no consista en dinero;

H) Fijar las normas generales para la confección de los balances y comprobar su exactitud;

I) Ejercitar las facultades de inspección y supervigilancia sobre las operaciones de crédito que realicen las Sociedades en la forma que establezcan las leyes especiales;

J) Informar a las instituciones de crédito del Estado sobre las So. ciedades que deseen realizar operaciones de crédito;

K) Proponer al Presidente de la República la revocación de la autorización de existencia de las Sociedades en los casos previstos por la ley o cuando de las investigaciones que se practiquen re. sulte que la administración se ha llevado en forma fraudulenta a manifiestamente descuidada;

L) Intervenir en las liquidaciones $y$ peticiones de declaración de quiebra de las Sociedades;

M) Resolver en el carácter de árbitro arbitrador sin ulterior recurso, las dificultades que se susciten entre los accionistas y entre éstos 
o terceros con la Sociedad, cuando las partes de común acuerdo lo soliciten;

N) Resolver en el mismo carácter las dificutades que se produzcon con motivo del acuerdo del Directorio de una Sociedad de no dar curso a un traspaso de conformidad a la ley;

N) Velar porque los organizadores o administradores de una sociedad que no alcanzare a obtener su instalación legal, restituyan todas las sumas que hubieren recibido por las acciones subscritas y todos los aportes que se hubieren hecho a la Sociedad; y aplicar las sanciones correspondientes;

O) Ejercer las demás facultades y cumplir las demás obligaciones que le correspondan de conformidad con las leyes especiales.

España y Suiza, en cambio, procuran prescindir de todo control por parte del poder Ejecutivo.

El Estado interviene, pero sólo dentro de las atribuciones que comun. mente le son propias por medio del Registro Mercantil o Registro de Comercio o por medio del Poder Judicial.

Esto no quiere decir que en los dos países aludidos no exista control sino que se ha elegido un sistema radicalmente diferente del que establecen las leyes chilenas.

España y Suiza han preferido el control por medio de la reglamentación de la institución, estableciendo muy cuidadosamente, en sus respectivas leyes, los derechos y obligaciones de los accionistas y de los administradores $y$ sus respectivas responsabilidades facultando a quien sea perjudicado para impugnar los acuerdos ilegales ante el Poder Judicial.

Por eso podemos decir que las cuatro columnas de los regímenes español y suizo son:

A) La reglamentación de la institución;

B) La responsabilidad de los administradores:

C) El derecho de impugnación; y

D) La intervención judicial calificada.

Estas conclusiones sufren, sin embargo, una excepción en España, según los artículos 151 y 171, que dan intervención efectiva al Poder Ejecutivo, sea para impedir la desaparición de las sociedades, sea para vigilar su liquidación, cuando el interés social, económico o del público así lo exija $\alpha$ juicio del Gobierno.

Sobre estas bases, Suiza legisla mós detalladamente acerca de la responsabilidad de los administradores y España da mayor fuerza a la intervención del Poder Judicial; pero cabe hacer notar que en ninguno do estos dos países interviene el Poder Judicial para aprobar estatutos 0 auto. rizar la formación de sociedades, como sucedía en época antigua, por ejemplo, en la primitiva ley italiana o en la ley noruega, y como se estableció en el proyecto peruano del Dr. Elmore, sino simplemente, para resolver los conflictos de derecho y amparar el reclamo del débil contra el fuerte $\mathrm{y}$. en general, de todo aquel cuyo derecho haya sido violado. 
En el Perú, de otro lado, reina la más absoluta imprevisión, es notoria la escasa reglamentación, el derecho de impugnación es prácticamente desconocido, la responsabilidad de los administradores rara vez puede hacerse efectiva y el Poder Judicial sólo interviene en los conflictos más initantes.

Unicamente para la vigilancia de los Bancos, Compañías de Seguros y Compañías de Capitalización interviene directamente el Estado por me. dio de la Superintendencia de Bancos, pero ésto se refiere sólo a entidades financieras de carácter especializado.

Entre estos tres sistemas de libertad completa, control absoluto o reglamentación legal, ¿cuál debe preferirse? ¿Acaso debería buscarse un método distinto?

Algunos pensarán que debe respetarse la libertad contractual y permitir que los individuos en los pactos sociales estipulen, sin intervención alguna del Estado, las obligaciones a que desean someterse.

Otros dirán lo contrario o sea que el Gobierno debe intervenir en las sociedades, para vigilar los intereses de los asociados.

Nosotros pensamos que, como dice Emile Gaillard, (1) "si bien la sociedad anónima se funda en un contrato libremente estipulado por las partes, tal contrato debe ejecutarse según la común intención de quienes lo celebran $y$, dentro de tal común intención está siempre que el interés social no sea violado por dolo o culpa lata, pues al entrar en la sociedad la minoría no ha tenido la intención de hacer liberalidades a la mayoría o de darle el poder de dilapidar su aporte. Ella tiene el derecho propio de no ser explotada y para ello se requiere que el Estado vele en alguna forma por los intereses de la minoría y de los acreedores".

¿Cúál será esta forma?

Nosotros pensamos que siguiendo la tendencia moderna más común, el control directo por el Poder Ejecutivo a través de Superintendencias o entidades análogas sólo cabe respecto a las sociedades anónimas que por dedicarse a actividades monetarias tienen influencia fundamental en la vida económica del país y que, por consiguiente, deben ver vigiladas para evitar que el fracaso de una de ellas pueda originar trasiornos en la economía nacional. En los demás casos debe predominar la libertad reglamentada y responsable, tal como rige en las leyes española y suiza.

Como dijimos en otra oportunidad, la intervención del Estado origina una demora extraordinaria para la organización de las sociedades anónimar, tiende a burocratizarlas, ocasiona gastos que no siempre están justificadas por las garantías que el control ofrece, da lugar a la intervención de la política en el movimiento de los negocios particulares, permite que los intereses económicos pongan en movimiento sus influencias cinte el Poder Público o ante sus amistades en la Administración Pública para impedir la fundación $o$ el desenvolvimiento de las empresas competidoras, da lugar a que los fundadores atribuyan a las compañías una solvencia o una seriedad que no tienen, si hay funcionarios complacientes que toleran ciertas

(1) La Société Anonyme de demain. Librairie du Recueil Sirey, Paris. 
deficiencias; $y$, finalmente, si se trata de un control riguroso, hace que desaparezca el secreto de los negocios y crea una intromisión constante y odiosa por parte del Estado en las actividades privadas. La vigilancia del Estado no debe realizarse en forma tan inmediata. El objeto de éste no es manifestar ni llevar de la mano, por decirlo así a cada uno de los ciuda. danos, sino dictar normas que garanticen suficientemente las relaciones económicas $\mathrm{y}$ que sancione pronta $\mathrm{y}$ debidamente $\alpha$ los infractores.

La libertad completa, de otro lado, como se ha dicho anteriormente, tampoco se justifica ya que conduce al libertinaje y origina grandes abusos.

La limitación de la responsabilidad de sociedades anónimas es indudablemente un privilegio que concede la ley.

La posibilidad de administrar dinero ajeno aún contra la voluntad del dueño y sujetándase a lo que decida la mayoría de votos es también otro derecho excepcional.

La responsabilidad de los administradores y de las sociedades anónimas respecto de accionistas $Y$ acreedores es igualmente un hecho notorio de que no puede despreocuparse la ley.

Por eso, aunque somos partidarios de la libertad de contratación, consideramos que en este caso, la libertad debe ser reglamentada, en la misma forma que nuestro Código Civil o las demás leyes de la República reglamentan la vida de los individuos sin oprimirlos, pero obligándolos a discurrir por cauces legítimos y señalándoles responsabilidades y penas para cuando se aparte de ellos.

Una reglamentación de esta naturaleza significa tan solo amparar la libertad individual y evitor el desenfreno.

\section{CAPITULO II}

\section{Bases del Control}

\section{Definiciones}

\section{Introducción}

Hemos dicho ya que habitualmente todas los paises procuran controlar en alguna forma las sociedades anónimas $y$ hemos visto, así mismo, cuál es la posición básica que en esta materia adoptan Chile, España, Suiza y el Perú: el primero estableciendo la intervención direcía del Poder Ejecutivo: el último sosteniendo la libertad casi cbsoluta y los otros dos pronunciándose por la libertad reglamentada.

Corresponde ahora profundizar un poco más el estudio de tales bases examinando como se define en cada legislación esta clase de sociedades. 


\section{Generalidades}

De un modo general, toda sociedad anómina debe gozar de ciertas caracieristicas, tales como:

A) Personalidad;

E) Limitación de responsabilidad;

C) División del capital en acciones o porciones;

D) Posibilidad de transferir las acciones con mayor o menor libertad;

E) Denominación propia;

F) Un fin determinado.

Las cuatro legislaciones que nos ocupan, definen la institución reproduciendo en alguna forma estos principios pero no siempre con igual detalle Y precisión.

\section{Legislación chilena}

En Chile el art. 424 define la sociedad anónima como una persona jurídica formada por la reunión de un fondo común, suministrado por accionistas responsables sólo hasta el monto de sus respectivos aportes, administrada por mandatarios revocables y conocida por la designación del objeto de la empresa.

Se advertirá que esta definición contiene los elementos fundamentales enumerados al comienzo, salvo que no indica que el capital debe ser dividido en acciones o porciones.

También debe anotarse que establece que la sociedad debe ser conocida por la designación del objeto de la empresa. Esto se precisa aún más en el artículo $9^{\circ}$ del Reglơmento diciendo que no se admitirá como nombre de una sociedad anónima, el de una persona natural o jurídica, cuando al mismo tiempo no se indique el objeto de la sociedad; y que el nombre de toda sociedad anónima, que se constituya en el país deberá indicarse en español.

En cuanto al fin, conviene advertir que, de acuerdo con el artículo 429, debe respetar el orden público, las leyes y las buenas costumbres.

\section{Legislación española}

En España, la ley no contiene una definición expresa, pero, en los artículos 1, 2, 43 (inciso 5\%), 46 y 11 (inciso 3c), establece cuales son todos los elementos necesarios para que exista una sociedad anónima.

Tratándose de la denominación sólo pone por taxativas, en el art. $2^{\circ}$, que deberá contener, necesariamente, la indicación de que es sociedad anónima y la garantía habitual de que no podrá adoptar el nombre de otra sociedad pre-existente.

Con respecto al fin sólo lo limita en el art. $3^{\circ}$ diciendo que la sociedad anónima no podrá tener por objeto la representación de intereses colec- 
tivos, profesionales o económicos atribuídos a otras entidades por la ley con carácter exclusivo.

Es de notar, igualmente, que la ley española, sin perjuicio de establecer tácitamente la trasmisibilidad de las acciones permite que se pacte trabas a la libre disposición diciendo en el art. 46 que las limitaciones a la libre transmisibilidad de la acción sólo serán válidas frente a la Sociedad cuando estén expresamente impuestas por los Estatutos.

\section{Legislación suiza}

En Suiza el art. 620 define claramente la sociedad anónima con todos los atributos que le son propios, diciendo que es "aquella que se forma bajo "una razón social, cuyo capital queda determinado por adelantado, dividido "en acciones, y cuyas deudas no están garantizadas sino por el activo social".

Es notable la ley suiza por cuanto expresamente permite, en el art. 950, que las sociedades anónimas formen libremente su razón social, y las autoriza paro hacer figurar en ellas nombres de personas. También cabe remarcar el hecho de que en Suiza, según el art. 620 antes citado, la sociedad anónima puede oganizarse para un fin no económico y que, de acuerdo con el art. 686, cabe estipular limitaciones al derecho de trasmitir las acciones, por motivos previstos en los estatutos y aún convenir que se podrá rechazar la inscripción de la trasmisión sin expresión de causa.

\section{Legislación peruana}

Según el inciso $3^{\circ}$ del art. 130 de nuestro Código de Comercio, la sociedad anónima es aquella en que formando el fondo común los asociados, por partes 0 porciones ciertas, figuradas por acciones $\circ$ de otra manera indubitada, encargan su manejo a mandatarios o administradores amovibles que representen a la compañía bajo una denominación apropiada al objeto - empresa a que se destine sus fondos.

En el art. 124 le confiere el carácter de persona jurídica.

Se advierte a primera vista que la definición nuestra es defectuosa, pues, aunque contiene los elementos concernientes a la división del capital en acciones y a la denominación de la sociedad, se falta expresar que la responsabilidad de los accionistas está limitada al valor de sus aportes, principio que sólo consagra después en los artículos 161 y 162.

Del mismo modo es de advertir que afecta el nombre de la sociedad al objeto de ésta; $y$ que no se refiere a la libre trasmisión de las acciones ni a los fines que pueda perseguir la empresa.

\section{Crítica}

De todo lo expuesto se deduce las siguientes conclusiones:

A) A nuestra legislación le falta una definición completa que contenga el elemento esencial que caracteriza a la sociedad anónima, o sea, la limitación de su responsabilidad; 
2) Corzideramos peligroso el sistema suizo en virtud del cual puede incedirze la libre trasmisión de las acciones estipulando en los estatutos que poçró negarse la inscripción de las transferencias, aún sin expresión de causa, pues esto sin duda podría entre nostoros originar abusos.

En este sentido estamos de acuedo con el principio establecido en el crt. 46 de la ley española, pero creemos que debería irse más lejos en la reglamentación impidiendo tachar las cesiones sin expresión de causa;

C) Tampoco estamos de acuerdo con las legislaciones de Chile y del Perú en cuanto exigen que la denominación de la sociedad haga rếerencia al objeto o empresa a que se destine los fondos de ésta.

Resulta muchas veces casi imposible poner en el nombre de una sociedad el objeto a que se dedica si sus fines son múltiples o demasiado genéricos. De esie modo resultaría un nombre sin contenido. Además, muchas veces los nombres de los socios incorporados a la razón social contribuyen a acreditar a la sociedad y los nombres de fantasía le permiten ser fácilmente reconocida.

No encontramos ninguna razón válida, por consiguiente, para obligar a la sociedad a llevar un nombre en que esté incluído su objeto.

En la práctica se ha demostrado entre nosotros, que el principio no fun. ciona, pues, a pesar de la prohibición del Código, las sociedades eligen sus. nombres caprichosamente y nadie ha logrado impedirlo.

El buen nombre de una persona, su reputación, etc., constituyen un verdadero capital y sería injustificado prohibir que sea aprovechado cuando tal persona se incorpora a una sociedad. En la época moderna ya nadie cree que una sociedad es colectiva por el simple hecho de figurar en su razón social el nombre de uno de sus dueños, pues basta agregar a ta] nombre el vocablo de "sociedad anónima", para que se sepa la existencia de limitación de responsabilidad.

En este sentido estamos de acuerdo con la solución adoptada por la ley suiza. Como en dicho país, podría establecerse principios que reglamen. ten de un modo general el uso de las razones de comercio rodećndolas de las garantías necesarias para evitar duplicidades, confusiones o engaños.

D) Debe permitirse a las sociedades anónimas perseguir no solamente fines mercantiles o civiles sino también de naturaleza no económica, por las razones ya expresadas anteriormente.

\section{CAPITULO III}

\section{El control en la constitución de las sociedades anónimas}

La constitución de la sociedad anónima puede sujetarse a variadísimos procedimientos y medios de control. Así en Chile es un procedimiento eminentemente administrativo; en España y Suiza puede ser simultáneo o sucesivo; $Y$, en el Perú, sólo es simultóneo. 


\section{Sistema chileno}

\section{A. Procedimiento.} etapas.

En Chile el procedimiento se caracteriza por los siguientes actos o

a) Las sociedades, según el art. 86 del Decreto con fuerza de ley $N^{\circ} 251$, deberán ser precedidas en su formación por un prospecto, folleto o circular firmado por sus organizadores, en que se exprese todos los detalles concernientes a la sociedad por constituirse, $y$ en que se consigne especialmente el valor que se atribuye a las propiedades que constituyen aportes de capital, con indicación de los títulos que comprueben su dominio en que se haga una síntesis de los informes periciales concernientes $\alpha$ los aportes no consistentes en dinero; $y$ en que se indique el número de acciones asignadas a los organizadores y lo que se destine para gastos de formación (art. 87 del Decreto 251).

b) Este prospecto se deposita en las oficinas de la Superintendencia de Compañías anónimas y se inscribe en un libro especial.

c) A continuación, la Superintendencia expide un certificado del depósito (art. 86 del Decreto con fuerza de Ley $\mathrm{N}^{\circ}$ 251).

d) Los fundadores proceden entonces a otorgar la escritura de constitución en que insertan el certificado emitido por la Superintendencia.

e) Los organizadores depositan a nombre de la sociedad en formación, los fondos que reciban por las suscripciones, en cuentas bancarias de depósito (art. 10 del Reglamento de 30/11/46).

f) Llenadas las formalidades antes descritas, se presenta una solicitud al Ministerio de Hacienda con tres copias autorizadas de la escritura social (art. $2^{\circ}$ del Reglamento).

g) El Ministerio pide informe a la Superintendencia de sociedades anónimas (art. 6\% del Reglamento).

h) También puede pedir informe a la Dirección General de Impuestos Internos (art. 6\% del mismo Reglamento).

i) Con estos informes el Ministerio o los interesados hacen las observaciones que encuentren pertinentes $y$, si el Ministerio decidiera sostener sus observaciones, los solicitantes deberán otorgar una escritura introduciendo en el pacto social las reformas exigidas por el Minisierio (art. $7^{\circ}$ del Reglamento).

j) Después de ello se expide el Decreto del Presidente de la República autorizando la existencia de la sociedad o denegándola (art. 427).

k) La denegatoria debe ser motivada (art. 439).

1) Autorizada la sociedad debe ser inscrita en el Registro de Comercio.

11) Para terminar se publica en el diario oficial, los decretos y extractos concernientes a la constitución de la sociedad (art. 440).

m) Concluído el procedimiento deberá comprobarse que se ha cumplido con los requisitos fijados por el Presidente de la República y que se ha hecho efectiva la cuoto correspondiente al capital; $y$, entonces, se expide nuevo Decreto por el Presidente de la República declarando que la compá̃ía 
se halla legalmente instalada y señalándole plazo para comenzar sus funciones (art. 434 del Código).

\section{B. Garantías.}

La fundación de toda sociedad está rodeada de las siguientes garantías:

a) No se da curso a ninguna solicitud para la formación de una compañía si no fuera firmada por un número de suscritores que llegue por lo menos a la tercera parte de las acciones que forman el capital (art. 428 del Código).

b) Se prohibe la cutorización cuando de la escritura social aparezca que el capital creado no es efectivo o que no está suficientemente asegurada su realización o que no es proporcionado a la magnitud de la empresa o que el régimen de la sociedad no ofrece a los accionistas garantías de buena administración (art. 430).

c) Debe depositarse en un banco los fondos que se reciban en pago de suscripciones, según lo expuesto anteriormente.

d) La escritura social deberá expresar: (Ârt. 426)

(1) El nombre, apellido, profesión y domicilio de los socios fundadores;

(2) El domicilio de la sociedad;

(3) La empresa o negocio que la sociedad se propone y el objeto de que toma su denominación, haciendo de ambos una enunciación clara y completa;

(4) El capital de la compañía, el número y cuota de las acciones en que es dividido, y la forma y plazos en que los socios deben consignar su importe en la caja social;

(5) La época fija en que deben formarse el inventario $y$ balance $y$ acordarse los dividendos;

(6) La duración de la compañía;

(7) El modo de la administración, las atribuciones de los administradores Y las facultades que se reserve la asamblea general de accionistas;

(8) La cuota de los beneficios que debe quedar en las arcas de la compañía para formar un fondo de reserva;

(9) El déficit del capital que debe causar la disolución de la sociedad;

(10) La forma en que deben hacerse la liquidación y división de los haberes sociales, llegado el caso de la disolución;

(11) Si las diferencias que les ocurran durante la sociedad deberán ser - no sometidas a la resolución de arbitradores $\mathrm{y}$ en el primer caso, la forma en que debe hacerse el nombramiento;

(12) Los demás pactos que acordaren los socios.

e) Para que una sociedad anónima pueda ser decretada legalmente instalada deberá probar, con las escrituras públicas respectivas, que el capital se encuentra íntegramente suscrito y acreditar con los comprobantes del caso, que ha dado cumplimiento a las condiciones fijadas por el Presidente de la República para la instalación legal de la sociedad. La Superintenden- 
cia podrá efectuar al efecto la comprobación que estime necesaria (art. 8? del Reglamento).

f) En defecto de otra estipulación, todo aporte que no consista en dinero está estimado por peritos y la estimación seráa aprobada por la junta general de accionistas (art. 443).

g) El Código declara en su artículo 459 que los actos administrativos ejecutados antes de obtenerse la autorización del Presidente de la República, no comprometen la responsabilidad de la Compañía, a no ser que hayan tenido por objeto trabajos preparatorios $u$ otras operaciones necesarias al planteamiento de la sociedad.

h) La autorización del Presidente de la República queda sin efecto si vence el plazo señalado por éste sin haberse pagado el capital prometido, o sin haberse completado la suscripción del mismo, o sin haberse principiado las operaciones de la sociedad.

i) También es nula la sociedad si se omite en la escritura social cualquiera de las formalidades estatuídas por la ley (art. 441).

j) No pueden ser enajenadas durante dos años las acciones que a título de remuneración se entreguen a los fundadores o por aporte en natura. (art. 95).

Los promotores responden en tal caso como socios colectivos por las obligaciones sociales.

\section{Sistema español}

En España la fundación de las sociedades puede ser simultánea o sucesiva.

\section{A. Procedimiento.}

La fundación simultónea se hace por simple escritura pública en que los interesados acuerdan lo que tengan por conveniente dentro de los marcos de la ley. Esta escritura debe inscribirse en el Registro Mercantil para que la sociedad adquiera personalidad jurídica (arts. 6 y 9).

Para la fundación sucesiva debe observarse las siguientes reglas:

a) Los promotores redactan un programa de fundación en que se especifican todas las condiciones generales de la sociedad y en especial los derechos o ventajas particulares que se reservan y la naturaleza $\mathrm{y}$ valor de las aportaciones no dinerarias. También se hace alli referencia al lugar en que estará a disposición de los suscritores una memoria explicativa y un informe técnico sobre la valorización asignada a los aportes en natura (art. 17).

b) El programa se deposita en el Registro Mercantil, publicándose un extracto en el Boletín Oficial del Estado (art. 18).

c) Llenados estos requisitós se procede a la suscripción de las acciones que se hace constar en un boletín extendido por duplicado con los datos pertinentes (art. 19).

d) En el plazo mínimo de seis meses contados a partir del depósito del programa de una fundación en el Registro Mercantil, los promotores convocan a una junta constituída con los siguientes tines: 
(1) Aprobación de las gestiones realizadas hasta entonces por los promo. tores;

(2) Aprobación de los estatutos sociales;

(3) Aprobación del valor que se haya dado a las aportaciones no dinerarias, si las hubiere:

(4) Aprobación de las ventajas particulares reservadas a los promotores, si las hubiere;

(5) Nombramiento de las personas encargadas de la administración de la sociedad;

(6) Designación de la persona o personas que deberán otorgar la escritura fundacional de la sociedad.

Esta junta sólo por unanimidad de votos puede modificar el contenido del programa de fundación (art. 23).

e) En los 30 días siguientes a la celebración de la junta se otorga la escritura de constitución la cual se inscribe en el Registro Mercantil dentra de los 30 días siguientes $\alpha$ su otorgamiento (arts. 25 y 26).

\section{B. Garantías}

La ley española estipula las siguientes seguridades en la fundación de las sociedades:

a) Eil capital debe ser íntegramente suscrito $y$, por lo menos, desembolsado en una cuarta parte (art. 8\%).

b) Se permite autorizar a los administradores para que aumenten el capital pero a condición de que esta cutorización no pase de la mitad del capital nominal de la sociedad y de que el capital autorizado no pueda estar. representado por acciones ni llevado al pasivo del balance.

c) La escritura social exprescrá:

(1) Los nombres, apellidos y demós generalidades necesarias de los fundadores.

(2) La voluntad de los otorgantes de fundar una sociedad anónima.

(3) Los estatutos que han de regir la sociedad, en los que se hará constar:

I) La denominación de la sociedad;

II) El objeto social;

III) La duración de la sociedad;

IV) La fecha en que dará comienzo a sus operaciones;

V) El domicilio social y los lugares en que vaya a establecer sucursales, agencias o delegaciones;

VI) El capital social, expresando el número de acciones en que estuviera dividido, el valor nominal de las mismas, su categoría o serie, si existieren varias, $y$ si son nominativas o al portador;

VII) La parte de capiral social no desembolsado y el modo en que han de satisfacerse los dividendos pasivos;

VIII) La designación del órgano u órganos que habrán de ejercer la administración, y el modo de proveer las vacantes que en ellos se produzcan, indicando quién ostenta la representación de la sociedad; 
IX) Los plazos y formas de convocar y constituir las juntas de socios tanto ordinarias como extraordinarias;

$\mathrm{X})$ La forma de deliberar $\mathrm{y}$ tomar acuerdos.

(4) El metálico, los bienes o derechos que cada socio aporte, indicando el título o el concepto en que lo haga, el valor que haya de atribuirse a las aportaciones no dinerarias y el número de acciones recibidas en pago.

(5) Los demás pactos lícitos que convengan a los socios.

d) Se prohibe trasmitir acciones mientras la sociedad no está inscrita en el Registro Mercantil (art. 14).

e) Se declaran nulos los pactos reservados.

f) Se declara solidariamente responsables a los gestores frente a las personas con quienes hubieran contratado en nombre de la sociedad para el caso en que ésta no quede aceptada dentro del plazo de tres meses de su presentación al Registro Mercantil.

g) Constituída la sociedad y dentro de un plazo mínimo de cuatro meses los administradores deben revisar la valorización de las aportaciones no dinerarias; y dentro de los cuatro meses siguientes cualquier accionista puede solicitar al Juez de Primera Instancia el nombramiento de un perito que revise la valorización efectuada por los administradores (art. 32).

h) También debe aprobarse por la junta general las adquisiciones de bienes a título oneroso que realice la sociedad dentro del primer año de su funcionamiento.

i) Los fundadores sólo pueden reservarse ventajas que lleguen hasta $10 \%$ de los beneficios y por un plazo no mayor de 15 año (art. 12).

j) Los fundadores están obligados a realizar todo lo necesario para obtener la inscripción de la sociedad, y responden solidariamente frente $\alpha$ ella y frente a tercero de la aportación de la cuarta parte del capital suscrito, de la realidad de las aportaciones no dinerarias y de su valorización, de la inversión de los fondos destinados al pago de los gastos de constitución $y$ de cuantas declaraciones hagan en la escritura fundacional.

La misma responsabilidad alcanzaró a las personas por cuya cuenta hayam obrado los fundadores.

\section{Sistema suizo}

Como hemos expresado anteriormente, las sociedades anónimas pueden también fundarse en Suiza en forma simultánea o sucesiva.

\section{A. Procedimiento.}

Para la fundación simultánea basta que los organizadores constituyaun la compañía mediante un acto auténtico y que lo inscriban en el Registro de Comercio (art. 638).

Para la fundación sucesiva se procede así:

a) Se redacta por los fundadores el proyecto de estatutos (art. 629). (art. 63):

b) Los fundadores preparon un informe detallado $y$ justificado sobre

(1) Los aportes en natura;

(2) Los bienes por adquirir; $Y$ 
(3) Las ventajas que han de otorgarse a los fundadores o a otras personas.

c) Se deposita una copia de este informe en original o copia en las oficinas de recepción de las suscripciones.

d) Si las acciones se ofrecen mediante suscripción pública debe hacerse además un prospecto que firman todos los fundadores, (art. 631), pero este prospecto se omite si el boletín de suscripción contiene la firma de los fundadores y los detalles generales exigidos para el prospecto.

e) Llenadas las anteriores formalidades previas, se procede $\alpha$ la suscripción de las acciones (art. 632).

f) Cubierta la suscripción, se procede a la reunión de la asamblea constitutiva que discute los estatutos y los aprueba no pudiendo hacer sino modificaciones de detalle, salvo consentimiento unánime de los suscritores para que se introduzca reformas de mayor importancia (arts. 634 y 635).

g) Las decisiones de la asamblea se hacen constar en un acto auténtico que firman todos los fundadores en presencia del funcionario competente, debiendo agregarse a este acto los estatutos primitivos y los aprobados, así como el prospecto $\mathrm{y}$ el informe de los fundadores si lo hubiere (arts. 637,638 y 639).

h) El acto auténtico así acordado, se inscribe en el Registro de Comercio (arts. 640 y 643).

i) Se da cuenta de la constitución de la sociedad publicando una copia de la inscripción en la Hoja Suiza de Comercio.

\section{B. Garantías.}

En Suiza, como en España, la ley exige múltiples garantías para la constitución de la sociedad, como son las siguientes:

a) El capital debe quedar íntegramente suscrito (art. 635).

b) Debe exigirse el pago de, por lo menos, el $20 \%$ del valor nominal de cada acción; y, en todo caso, de una suma no menor de 20,000 francos, en efectivo (art. 633).

c) Se requiere una mayoría de $2 / 3$ del capital para aprobar, en la asamblea constitutiva, los aportes en natura, la adquisición de bienes y el otorgamiento de ventajas a particulares (art. 636).

d) Si un accionista hace un aporte en natura, los estatutos deben indicar el objeto de este aporte, su valor y el precio por el cual es aceptado, la persona del accionista $y$ el número de acciones que recibe en cambio (art. 628).

e) Si la sociedad debe adquirir bienes de un accionista o de un tercero, los estatutos deben designar estos bienes, indicar el nombre del accionista o del tercero y la prestación debida por la sociedad (art. 628).

f) Si al constituirse la sociedad se estipula ventajas en favor de los fundadores, o de otras personas, los estatutos deben indicar el nombre de los beneficiarios y determinar exactamente la extensión y el valor de tales ventajos.

g) La sociedad debe tener no menos del número de accionistas que sea necesario para constituir su administración (art. 625), no pudiendo su número ser menor de 3 . 
Cuando el número de accionistas cae por debajo de esta cifra o cuando la sociedad no pasee los órganos prescritos, el juez puede pronunciar la disolución a solicitud de un accionista o de un acreedor, a menos que la sociedad restablezca la situación legal dentro de un plazo conveniente.

h) Los estatutos deben contener, por lo menos, lo siguiente:

(1) La razón social y la sede de la sociedad;

(2) El objeto $y$ fin de la empresa;

(3) El monto del capital social, el valor nominal de las acciones y su especie y si ocurre el caso, el número de aquellas que son nominativas o al portador;

(4) La convocación de la asamblea general y el derecho a voto de los accionistas;

(5) Los órganos encargados de la administración y del control, así como la forma de representación de la sociedad;

(6) El número de acciones que los administradores estón obligados a depositar;

(7) La forma que debe observarse para las publicaciones de la sociedad. i) Sólo son válidas cuando figuran en los estatutos las disposiciones que conciernen $\alpha$ :

(1) Revisión de estatutos, en particular la extensión o la reducción del círculo de lás operaciones, el cumento o la disminución del capital social y la fusión, todo en la medida en que no esté confiado a las prescripciones de la ley:

(2) La participación de los administradores en el beneficio neto;

(3) El otorgamiento de intereses suplementarios;

(4) La duración de la empresa;

(5) La fijación de un monto superior al mínimo legal para la liberación de las acciones;

(6) Las penas convencionales para el caso de demora en la liberación;

(7) La facultad de convertir las acciones nominativas en acciones al portador e inversamente;

(8) La prohibición de transferir las acciones nominativas, o las restriccioes a que se someterá esta transferencia;

(9) La emisión de acciones preferenciales, de bonos de goce y de partes de fundador;

(10) La restricción del derecho de voto de los accionistas y de su derecho a hacerse representar, así como la emisión de acciones con derecho $\alpha$ voto privilegiado;

(11) Los casos no previstos por la ley en que la asamblea general no pueda resolver sino con una mayoría calificada;

(12) La facultad de delegar ciertos poderes de administración a algunos de sus miembros o a terceros;

(13) La organización del control, los derechos y las obligaciones de los controladores, si estas disposiciones van más allá de la ley. 


\section{Sistema peruano}

A. Procedimiento.

En el Perú, de un modo general, como ya hemos dicho, impera el sistema de constitución simultánea, salvo para los Bancos, Compañías de Seguros y Compañías de Capitalización, que están sujetas a la intervención de la Superintendencia de Bancos; y las Compañías Mineras que, de acuerdo con el art. 212 del nuevo Código de Minería, deben ser autorizadas por el Director de Minería o por el Jefe Regional de Minería.

No vamos a ocuparnos de los Bancos y demás entidades de carácter financiero, porque no es tal el fin de nuestra exposición y por ello debemos concretarnos tan sólo a las demás sociedades anónimas, sean comunes 0 mineras.

La generalidad de las sociedades anónimas se constituye, de acuerdo con ésto, en el Perú, mediante el otorgamiento de una escritura pública que se inscribe en el Registro Mercantil (arts. 124, 125 y 127).

Para las sociedades mineras deben presentarse a la autoridad minera una solicitud pidiéndole autorización y la minuta del contrato junto con informes técnica-económicos que justifiquen el objeto y fines de la compañía y el monto de su capital. Esta clase de compañías sólo puede iniciar sus operaciones después de inscritas en el Registro de Concesiones y Derechos Mineros.

\section{B. Garantías.}

a) La ley peruana no señala ningún mínimun de accionistas para las sociedades anónimas, limitándose a decir en el art. 124, que por el contrato de compañía dos o más personas se comprometen a poner en fondo común bienes, industria, o alguna de estas cosas.

b) Tampoco señala un mínimo de capital.

c) No obliga a la suscripción íntegra del capital. pagado.

d) Permite así que haya: Capital autcrizado; capital suscrito y capital

e) Prohibe los pactos reservados (art. 127).

f) Establece la responsabilidad solidaria de los fundadores que dejen de llenar las formalidades legales (arts. 127 y 128).

g) Establece que las compañías mercantiles se regirán por las cláusulas y condiciones de sus contratos, en cuanto ello no esté determinado y prescrito por las disposiciones del Código (art. 129).

h) Manda consignar en la escritura social, lo siguiente:

El nombre, apellido y domicilio de los otorgantes;

La denominación de la compañía;

La designación de la persona o personas que habrón de ejercer la administración, y modo de proveer las vacantes;

El capital social, con expresión del valor que se haya dado a los bie. nes aportados que no sean metálico, o de las bases según las que habrá de hacerse el avalúo: 
El número de acciones en que el capital social estuviere dividido y representado;

El plazo o plazos en que habró de realizorse la parte de capital no desembolsado al constituirse la compañía; expresando, en otro caso, quién o quienes quedan autorizados para determinar el tiempo y modo en que hayon de satisfacerse los dividendos pasivos;

La duración de la sociedad;

Las operaciones a que se destine el capital;

Los plazos y formas de convocación y celebración de las juntas generales ordinarias de socios, y los casos y el modo de convocar y celebrar las extraordinarias;

La sumisión al voto de la mayoría de la junta de socios, debidamento convocada y constituída, en los asuntos propios de su deliberación;

El modo de contar y constituirse la mayoría, así en las juntas ordinarias como en las extraordinarias para tomar acuerdo obligatorio;

Se podrá además consignar en la escritura, todos los pactos lícitos y condiciones especiales que los socios juzguen conveniente establecer.

i) No dice nada sobre los privilegios que se otorguen o puedan otorgarse a los fundadores 0 a terceras personas.

j) Para los aportes en natura se sujeta, primordialmente, a lo que establezca el pacto social (art. 179).

\section{Crítica general}

De toda esta exposición resulta lo siguiente:

A. El sistema chileno es muy complicado, da lugar al intervencionis. mo gubernativo, origina una tramitación morosa y favorece la burocracia, entrabando el libre ejercicio del comercio y de la industria.

B. El sistema español y el suizo reglamentan cuidadosamente la fundación de las sociedades, rodeándolas de las disposicones y garantáas más apropiadas.

C. El sistema peruano es sumamente deficiente pues le falian seguridades y disposiciones que podríamos juzgar elementales.

D. La modificación introducida por el Código de Minería, al dar intervención a la autoridad minera en la constitución de las sociedades anónimas, no encuadra dentro de los sistemas legislativas modernos que hemos examinado.

E. Si se aceptase el sistema del Código de Minería, habría que essablecer una vigilancia y registro especial para cada clase de sociedades anónimas según sus fines: en el Ministerio de Agricultura parc las nsgociaciones agrícolas; en el Ministerio de Fomento para las de irrigación o las industriales; en el Ministerio de Hacienda para las comerciales, etc. etc.; e iríamos así a una variedad no imaginable de leyes, registros y controles.

F. No debe confundirse la sociedad anónima, como organizcción jurídica que es igual a cualquier otra, ocúpese o no de minas, con la empresa minera, como dueña de minas.

Una sociedad anónima comercial puede ser dueña de minas sin variar 
su estructura, del mismo modo que un particular puede poseerlas sin variar su anatomía o fisiología.

G. Cualquier nueva ley peruana de sociedades anónimas debe propender a la unificación legislativa siguiendo el ejemplo de las leyes española y suiza; y como en ellas reglamentar la constitución de las mismas y detallar las garantías de que debe rodearse el acto y las responsabilidades de los fundadores.

\section{CAPITULO IV}

\section{El control durante la existencia de las sociedades anónimas}

El control de la vida de las sociedades anónimas supone regular:

1. Las obligaciones de los accionistas;

2. Los derechos de éstos;

3. Los límites de tales derechos;

4. Las garantías que de un modo general debe dar toda sociedad anónima en materia administrativa y económica a las mayorías, a las minorías y a los acreedores; y

5. La reglamentación de la responsabilidad emanada de la observancia o inobservancia de los respectivos principios.

\section{Obligaciones de los accionistas}

Las principales obligaciones de los accionistas son:

A) Aportar el capital;

B) Atribuir un justo valor a sus aportes;

C) Mantener su capital en la sociedad;

D) Cumplir su empeño el socio industrial, si lo hubiere.

A) El cporte de capital.

En los países bien organizados, el aporte de capital está rodeado siempre de una serie de seguridades fundamentales que examinaremos a continuación.

a) Los accionistas deben ser responsables del pago de sus aportes.

En Chile, los artículos 424 y 446 del Código de Comercio declaran que los accionistas son directa y exclusivamente responsables $\alpha$ la sociedad de la entrega del valor de sus acciones. En España, el artículo 44 de la ley dispone que el accionista deberá aportar a la sociedad la porción de capital no desembolsado en la forma prevista por los estatutos, o, en su defecto, por acuerdo de la junta general. El Código Suizo en sus artículos 620,633 y 680 determina, de un modo general, la respectiva obligación. El Código Peruano, en el artículo 161, hace responsables a los socios por los fondos que pusieron o se comprometieron a poner en la masa común.

Cumplen, pues las cuatro legislaciones con imponer esta obligación 
fundamental, que constituye uno de los elementos imprescindibles del contrato social, esto es el poner algo en común.

b) Deben ser nulas las acciones que no representan aporte real.

En Chile no se observa este principio ya que los accionistas industriales, que no aportan dinero sino trabajo, son admitidos según los artículos 446 y 447 del Código de Comercio, y sólo se manda pagar en dinero efectivo las acciones que no representan aporte en natura (artículo 116 y el Decreto con fuerza de ley $\mathrm{N}^{\circ}$ 251).

En España, en cambio, se cumple con el principio, pues el artículo 33 de la ley declara expresamente que será nula la creación de acciones que no respondan a una efectiva aportación patrimonial a la sociedad.

En los Códigos de Suiza y del Perú, el punto no está expresamente definido con relación a las sociedades anónimas, y consideramos que debería esclarecerse entre nosotros a fin de evitar dudas, pues el artículo 120 del Código de Comercio al referirse al contrato de Compañía dice que consiste en poner en común bienes, industria o alguna de estas cosas" y podría pensarse que, por ser una disposición común a todas las sociedades incluye a las anónimas. También se requiere rara impedir aportes ficticios o que, imaginando el pago de trehajos o servicios no prestadios, se pretenda entregar acciones a quienes no han hecho un aporte patrimonial.

En nuestro concepto, una característica de la sociedad anónima es que constituye una agrupación de capitales, de modo que no podría admitirse el otorgamiento de acciones que den participación en el capital a personas que sólo se han comprometido a prestar sus servicios en el futuro.

Estos últimos podrían recibir partes de fundador, bonos de goce u otra especie de títulos que den participación en las utilidades, pero no acciones que confieran derecho a voz y voto y a participar en la distribución del activo social.

En cuanto a los servicios ya prestados que, tienen un valor apreciable en dinero, la cuestión es diferente pues equivalen a un aporte real, sea del crédito existente por la remuneración que corresponda a los mismos, si no han sido pagados (siempre que ellos sean verdaderos y justamente valorados), sea de la remuneración misma que pudo ser en numerario o mediante la renuncia a percibirla a cambio de la recepción de acciones.

c) No debe permitirse emitir acciones por menos de su valor nominal.

El Código de Chile y el del Perú no dicen nada sobre la materia; pero, en cambio, la ley española en su artículo treinta y seis y la ley Suiza en su artículo seiscientos veinticuatro establecen esie orincipio expresamente, y se comprende que así sea desde que la emisión de títulos por debajo de su valor nominal significaría atribuir a la sociedad un falso capital.

d) Debe sancionarse la falta de pago.

(1) El cobro.

La legislación española en el artículo cuarenticuatro declara expresamente que la sociedad tiene el derecho de reclamar en vía ordinaria el cum- 
plimiento de la obligación del accionista o de proceder ejecutivamente contra él.

El Perú támbién permite la ejecución (art. 177).

En Chile y Suiza no hay disposición expresa de la ley, pero es evidente que el derecho de cobro por parte de la sociedad es una consecuencia necesaria de la obligación contractual asumida al suscribir las acciones.

(2) Pago de intereses.

España (art. 44), Suiza (art. 681) y el Perú (art. 178) penan con el pago de intereses la demora en la entrega de los aportes disponiendo el Código peruano que también puede reclamarse el importe de los daños Y perjuicios a quien los hubiera ocasionado con su morosidad.

(3) Venta de la acción.

Chile, en el artículo 444 del Código de Comercio, faculta a la sociedad para vender, por intermedio de un corredor de número, por cuenta $Y$ riesgo el socio moroso, las acciones que le corespondan cuando el accionista no pagare en las épocas convenidas su cuota o una fracción de ella.

España, en el artículo 44 de la ley, permite enajenar las acciones por cuenta y riesgo del socio moroso por medio de agente de cambio y bolsa, corredor de comercio colegiado o notario público sustituyendo el título originario por un duplicado.

(4) Pérdida de derechos.

En Chile (art. 444) la legislación permite además medidas drásticas, pues dice que cuando un accionista no pagare su cuota en la época convenida, la sociedad podrá apropiarse de las cantidades que éste hubiera entregado retirándole el título que tenga; y Suiza, en el artículo 681, faculta a la administración para declarar extinguidos los derechos de la suscripción, diciendo que en tal caso, la sociedad adquiere los pagos que se hayan hecho y que se halla autorizada para emitir nuevas acciones en sustitución de aquellas que así quedaren anuladas, agregando que si los títulos ya emitidos no fueran restituídos se publicaró la anulación en la Hoja Oficial Suiza de Comercio así como en la forma prevista por los estatutos.

Ia misma legislación suiza dispone que (art. 682), si la administración se propone declarar en mora a los accionistas, privándolos de sus derechos de suscritores, debe publicar por lo menos tres requerimientos de pago en la Hoja Oficial Suiza de Comercio y, además, en la forma prevista por los estatutos, otorgándoles un nuevo plazo, por lo menos de un mes, contado a partir de la última publicación; y estatuye que sólo puede pronunciarse la extinción si el accionista no paga dentro del nuevo plazo.

Para los títulos nominativos la notificación se hace también por carta certificada.

En el Perú, el artículo 171 del Código de Comercio declara que cuando las acciones no pagadas sean al portador y no comparezca el accionista, la Compañía podró acordar la cunulación de los títulos correspondientes cuando sea imposible toda reclamación personal y que en este caso las 
compañías podrán expedir títulos duplicados para enagenarlos por cuenta Y cargo del tenedor moroso.

(5) Rescisión.

En España (art. 44) y en el Perú (art. 177), se puede rescindir el contrato reteniendo la sociedad las cantidades ya recibidas por ella a cuenta de la acción.

(6) Otras sanciones.

Tanto Chile, en el artículo 444 del Código como Suiza, en el artículo 181, permiten a la sociedad establecer en los estatutos otra clase de samciones.

(7) Crítica.

El derecho de cobro, sea ejecutivamente o sea en vía ordinaria y el pago de intereses o de daños y perjuicios, si los hubiere, parecen incuestionables ya que no se trata sino de exigir el cumplimiento de una obligación como cualquier otra.

Cabe preguntarse, en cambio, si es mejor facultar a la sociedad, al modo de la legislación de Chile o de España para vender las acciones por medio de un corredor o de otro funcionario; o autorizar a la sociedad para anular los derechos del accionista de hecho y emitir nuevos títulos, tal como se hace en Chile y Suiza.

Sin duda la venta de las acciones por un corredor es un medio justo de ejecutar al deudor, pero no siempre resulta efectivo desde que puede ser que no produzca a la sociedad el íntegro del capital que la acción representa y que, en cambio, se ponga en circulación las acciones por menos de su valor nominal.

El sistema de anular la acción, de facto, por declaración de la so. ciedad, a primera vista parece muy drástico porque significa confiscar al accionista los aportes que haya hecho cualesquiera que ellos sean; pero en nuestro concepto es la mejor solución pues defiende más a las sociedades onónimas.

El accionista moroso no sólo deja de cumplir su obligación. Pone también en peligro la vida de la sociedad, $\mathrm{y}$, por consiguiente, el aporte de los demás accionistas, puesto que cuando se fija el capital de una sociedad se procede en vista de sus necesidades y de la financiación que requiere, lo que no se lograría si los accionistas, en todo o en parte, dejaran de cubrir sus aportes.

Además, los sistemas de venta por medio de corredores o de rescisión del contrato pueden dar lugar a procedimientos morosos y a oposiciones cue dificultan las actividades de la sociedad impidiéndole por un tiempo apreciable recibir los aportes que requiera.

Por eso, en la alternativa de adoptar medidas para impedir que se prive a los suscritores morosos de los aportes parciales que hayan hecho o de proteger a la sociedad para que cubra su capital con toda seguridad, evitóndole pleitos, es evidente que debe decidirse por el medio más rápido y seguro, pues lo que prima en estos casos es el interés de la sociedad y 
no el de los accionistas morosos. Interesa a la economía de todo país que se formen organizaciones sólidas cuya vida no se vea entrabada con juicios de cobro a los suscritores de acciones. Puede, sin duda, establecerse la obligación de devolver al accionista parte del aporte retenido cuando la pena llegue a ser excesiva.

No hay inconveniente, sin duda, para que también se estipulen otras sanciones en los estatutos, como lo permiten las leyes de Chile y de Suiza.

\section{e) Los cedentes y los cesionarios de acciones deben responder por el saldo impago.}

La legislación de Chile (art. 37 del Reglamento) establece que en los documentos de transferencia de acciones nominativas, o en escrito separado, deberá expresarse que, de conformidad con la ley, el adquiriente contrae la obligación de pagar las cuotas insolutas.

En España (art. 45) se indica que el cesionario de la acción no liberada responde solidariamente con todos los cedentes del pago de la parte no desembolsada, que todo pacto en contrario será nulo y que la responsabilidad de los cedentes prescribe a los tres años.

En Suiza, según el artículo 687, el adquiriente de una acción nominativa que no está íntegramente liberada responde por los pagos pendientes en favor de la sociedad. El cedente responde por un plazo de dos años.

En el Perú, según el artículo 171, también existe responsabilidad solidaria para la cesión de acciones nominativas.

La diferencia más saltante $\alpha$ este respecto es que, mientras que Chile (art. 36 del Reglamento), España (art. 34), y Suiza (art. 683), establecen que no podrá emitirse acciones al portador si no están íntegramente pagadas, en el Perú se autoriza la emisión de acciones de esta clase una vez desembolsado el $50 \%$ del valor nominal, declarándose que el cesionario de una acción al portador responderá del pago de los dividendos pendientes cuando se muestre como tenedor de los mismos y que si no comparece, haciéndose imposible toda reclamación personal, las compañías podrón acordar la anulación de los títulos correspondientes a las acciones por las que se hubieran dejado de satisfacer los dividendos exigidos para el completo pago del valor de cada una y que, en este caso, las compañías tendrán facultad de expedir títulos duplicados de las mismas acciones para enagenarlos a cuenta y cargo de los tenedores morosos de los anulados (art. 171).

Se comprenderá que el sistema peruano da a la sociedad un derecho ilusorio de perseguir al cesionario o deudor cuando éste se presente, pues es evidente que si no puede o no quiere pagar no se presentará.

Es cierto que faculta a la sociedad para anular los títulos correspondientes a las acciones por las que se hubiera dejado de satisfacer los dividendos, pero no señala cómo se probará que es imposible toda reclamación personal, siendo indudable que, como bien se anota en la Edición deI Código de Comercio publicada por don Miguel Antonio de la Lama, la apreciación de la imposibilidad de una reclamación personal es un asunto sumamente difícil.

Creemos que, como en todas las otras legislaciones, no debería permitirse en el Perú la emisión de acciones al portador que no se encuentren 
totalmente pagadas, pues de otro modo resulta prácticamente imposible 0 muy costoso perseguir al verdadero deudor $a$ hacer efectivo el derecho de la sociedad de anular las acciones y emitir nuevas.

\section{B) La justa valuación de los aportes.}

\section{a) Generalidades.}

Cuando el capital es aportado en moneda corriente no existe problema de valuación; pero cuando una o más personas ponen en la sociedad otros bienes muebles o inmuebles, ésto es, cuando hacen aportes en natura, surge la dificultad de fijarles un valor equitativo.

El que cede el bien exagera frecuentemente su precio y los demás tratan de reducirlo como sucede en todo contrato conmutativo. No pocas veces el aportante hace una tasación excesiva $\mathrm{y}$ en ciertas ocasiones ha ocurrido que el valor ha sido absolutamente ficticio y no ha correspondido ni remotamente a la realidad. Se ha fijado un precio abusivo atribuyendo así a la sociedad un capital en gran parte inexistente $y$ el fundador después se ha apresurado a vender sus acciones para liquidar tan ilícito provecho, obtenido a base de la especulación y del engaño. Por eso la mayor parte de las legislaciones cuida de regular celosamente esta materia.

En Chile, el artículo 443 del Código de Comercio determina que, en defecto de estipulación, todo aporte que no consista en dinero será estimado por peritos y que la estimación será aprobada por la junta general de accionistas.

En España, según el inciso e) del artículo 21, la junta constitutiva de las sociedades de constitución sucesiva aprueba el valor dado a las aportaciones no dinerarias si las hubiere; y, de acuerdo con el artículo 32. los administradores de la sociedad, dentro de un plazo de cuatro meses, a contar desde su constitución, deben proceder a revisar la valorización de tales aportes facultándose a cualquier accionista para solicitar, dentro de los cuatro meses siguientes a esta valuación, que el juez nombre un perito que la revise, correspondiendo al juez decidir cuál de las dos valuaciones es la justa. Si la revisión demostrara que el valor de los bienes aportados es inferior a la cifra oficialmente asignada, el socio aportante podrá optar entre que se le anule las acciones equivalentes a la diferencia, separarse de la sociedad o completar en dinero esa diferencia.

En Suiza, en las sociedades de constitución sucesiva, los fundadores deben redactar un informe detallado sobre la naturaleza de los aportes, los elementos para apreciarlos y el número de acciones entregadas en cambio. Este informe se deposita en cada oficina de suscripción. La asamblea constitutiva debe pronunciarse sobre este informe $\mathrm{y}$ sobre la valuación con voto de dos tercios del capital (art. 636). Tanto en las sociedades de fundación sucesiva como en las de fundación simultánea, los estatutos deben indicar el objeto del aporte, su valor y el precio por el cual es aceptado, la persona del accionista y el número de acciones que se le entregan en cambio.

En el Perú, según el artículo 179 del Código de Comercio, cuando el capital o la parte de él que un socio debe aportar, consiste en efectos, se hará su valuación de la misma forma prevenida en el contrato de socie- 
dad; a falta de pacto especial sobre ello, se haró por peritos elegidos por ambas partes y según los precios de la plaza; $y$, en caso de divergencia entre los peritos, se designará un tercero a la suerte entre dos personas propuestas por los interesados que figuren como mayores contribuyentes en la localidad, para que diriman la discordia.

\section{b) Crítica.}

De la comparación precedente resulta que en los países examinados se avalua los aportes en natura mediante convenio de las partes o por peritos; $y$ que rige además en España, el principio de revisión e impugnación a posteriori.

Entre estos sistemas consideramos que el mós acertado es el Suizo, esto es, el de la valuación por las partes (ya sea en el acto de fundación, en las sociedades de constitución simultónea o en la asamblea constitutiva en las de fundación sucesiva) basada en los informes de los fundadores y en la responsabilidad que éstos asumen por su dicho.

Nadie mejor que los contratantes, si están debidamente informados, puede apreciar el valor de los aportes o la necesidad y utilidad de éstos. Si alguien no lo conoce, tiene la posibilidad de hacerse asesorar por peritos o aconsejarse con personas entendidas, pero en ningún caso parece justo imponer como precio al aportante, el que otro (un perito) le señale, puesto que ello significaría desconocer el principio elemental de los contratos según el cual éstos son la expresión de la voluntad de quienes los acuerdan.

Si a los futuros consocios no les conviene la valuación o no pueden ponerse de acuerdo con el aportante, deben abstenerse de formar parte de la sociedad o no admitir el aporte.

Cabe sostener, claro está, que en las sociedades de fundación sucesiva, en que se ofrece acciones al público, el modesto accionista no tiene muchas veces conocimientos, medios, ni poder suficientes para apreciar $\mathrm{y}$ discutir el valor de los aportes que hacen los grandes accionistas y que por eso en interés de la sociedad debe exigir el Estado que la valuación se haga o pueda hacerse por peritos; pero a ello debemos responder que estamos de acuerdo con el Mensaje de Remisión del proyecto suizo, cuando dice que los peritajes tienden a retardar la constitución de las sociedades anónimas y no suministran garantías adecuadas si los fundadores tienen influencia tal que puede hacer que los peritos aprueben la valuación hecha por ellos mismos.

Más vale, por eso, que los fundadores expliquen detalladamente las razones por las cuales han hecho determinada valuación, y que se hagan responsables por las informaciones erróneas o dolosas que den al respecto. Así como estando la sociedad en marcha no se exige peritajes oficiales para la compra de un bien, por más importante que sea, no hay razón para imponerlos cuando se trata del aporte de los fundadores. No es indiferente tampoco, como bien dijo la Comisión Suiza, que los bienes que una persona se propone aportar a una sociedad anónima sean desacreditados por ur peritaje. 
El sistema español de valuación por la asamblea constitutiva, de revisión por los administradores e impugnación por los accionistas es a primera vista muy atractivo $\mathrm{Y}$ aparentemente más seguro; pero, en nuestro concepto, sus medidas protectoras si no se les tamiza, pueden resultar ilusorias o perjudiciales. De un lado, los primeros administradores generalmente son nombrados por los fundadores o en la asamblea constitutiva de modo que parece extremadamente difícil que enmienden sus valuacio nes. De otro lado, la facultad de cualquier accionista para impugnar las valuaciones, si no se le limita a casos precisos, puede originar juicios $y$ gastos innecesarios que entraben la vida de la sociedad en su momento más difícil, esto es cuando recién comienza su existencia; puede favorecer también las maniobras dolosas de los competidores que quieran desacreditar $a$ una nueva sociedad o entrabar su funcionamiento.

La valuación a posteriori es, además, injusta, puesto que las circunstancias cambian a veces de un momento a otro y lo que en un día es valioso y atractivo puede resultar más tarde inútil.

La solución según la cual el aportante tiene el derecho de apartarse de la sociedad si no acepta la nueva valuación, ha de resultar así mismo. en no pocos casos, de imposible ejecución, si el bien aportado ya ha sido empleado en el fin de la sociedad. Puede haber sido construído, si es un terreno, usado si es una maquinaria o herramienta, o consumido, si es perecedero. En tales casos no se ve qué podría hacer el aportante que no quiere dar mós dinero, ni se conforma con que se le reduzca el número de sus acciones, si no es exigir que la vida de la sociedad se mantenga paralizada durante los ocho primeros meses, esto es, mientras exista el riesgo de impugnación.

Por todo ello, insistimos, vale más atenerse a la valuación de las partes, hecha en forma clara y precisa y sujeta a responsabilidad de los aportantes en los casos de fraude, dolo, lesión u otro vicio semejante. Es aconsejable, si, admitir un corto plazo de impugnación por estos últimos conceptos, y un procedimiento sumario para resolverlos, como en España, a fin de que la estabilidad de la sociedad no quede perturbada por mucho tiempo con la posibilidad de acciones de esta clase.

C) Los accionistas deben mantener su capital en la sociedad.

Es evidente que no basta que los accionistas hagan sus aportes pues si los retirasen de la sociedad recibiéndolos en préstamo, haciéndose cargos en cuenta corriente, suscribiendo letras o en cualquier otra forma, el aporte de capital sería una farsa y la sociedad no podría cumplir sus fines. Por eso todas las legislaciones cuidan de que las sociedades no disminuyan su capital prescribiendo, para los casos excepcionales, determinadas formalidades.

El Código Chileno en el artículo 442 establece que el capital social seró fijado de una manera precisa e invariable $y$ que no podrá ser disminuído durante la sociedad. La severidad de este principio ha sido mitigada en el artículo 96 del decreto con fuerza de ley $\mathrm{N}^{\circ} 251$, según el cual sólo podró autorizarse las disminuciones de capital previo informe de la Superintendencia y siempre que aparezca que la parte de capital que se trata de disminuir es innecescria para los fines sociales. 
En España, este punto se halla previsto en los artículos 84, 97, 98 y 99 de la ley, en virtud de los cuales, para la reducción del capital, debe adoptarse el acuerdo en una junta de accionistas con la concurrencia de socios y de capital prevista en el artículo 58, o sea dos tercios del número de socios y del capital, si las acciones fueran nominativas y dos tercios de este último cuando las acciones sean al portador, salvo que el caso se vea en la segunda convocatoria, pues en esta bastará la mayoría de los accionistas y la mitad del capital desembolsado o sólo esta última representación cuando las acciones sean al portador. Aprobada allí la medida debe publicarse un aviso por tres veces en el Boletín Oficial y en tres periódicos de los de mayor circulación de la provincia en la que la sociedad tenga su domicilio, y sólo después de vencido este plazo de tres meses de la última publicación, puede hacerse la reducción si no se formula oposición por parte de los acreedores ordinarios, quienes están facultados para objetarla si sus créditos no son satisfechos o la sociedad no presta garantía.

Las garantías antes citadas no son obligatorias cuando la reducción del capital tenga por finalidad establecer el equilibrio entre el capital $y$ el patrimonio de la sociedad disminuído por consecuencia de pérdidas; y la reducción del capital es obligatoria para la sociedad cuando las pérdidas hayan disminuído su haber por debajo de las dos terceras partes de la cifra del capital social y hubiera transcurrido un ejercicio social sin haberse recuperado el patrimonio.

En Suiza, según los artículos 732, 733, 734 y 735, la asamblea general no puede decidir la reducción del capital social sino cuando se comprueba con un informe de revisión especial que las deudas quedarán completamente cubiertas por el capital reducido.

El informe de revisión debe emanar de un Sindicato de revisión o de una sociedad fiduciaria reconocida para estos efectos por el Consejo Federal Suizo. La institución de revisión debe estar representada en la respectiva asamblea general.

La decisión comprueba el resultado del informe de revisión e indica de qué modo debe ser efectuada la reducción del capital.

Una vez que la Asamblea General ha resuelto disminuir el capital social, se publica la decisión por tres veces en la Hoja Oficial Suiza de Comercio y, además, en la forma prevista por los estatutos, participando $\alpha$ los acreedores que dentro de los dos meses que sigan a la última publicación en la Hoja Oficial Suiza de Comercio deberán presentar sus acreencias y exigir el pago o garantías suficientes.

La reducción del capital no puede efectuarse sino una vez que haya expirado el plazo concedido a los acreedores y cuando éstos hayan sido pagados o garantidos; y no puede ser inscrita sino después que se haya comprobado por acto auténtico que se ha observado las prescripciones legales. Sin embargo, los avisos pueden suprimirse cuando la reducción se efectúe como resultado de pérdidas que disminuyan el capital social, pero siempre que la reducción no pase del monto de la pérdida. En tal caso tampoco se exige pago a los acreedores ni garantías específicas.

No se permite reducción del capital a menos de 50,000 francos por 
ser éste el mínimo que la ley señala para las sociedades anónimas (arts. 621 y 732).

En la legislación peruana, el artículo 175 del Código de Comercio dispone que los administradores podrán hacer la reducción si el capital efectivo restante, después de hecha, excediera en un $75 \%$ del importe de las deudas y obligaciones de la compañía y que en otro caso no podrá llevarse $a$ efecto hasta que se liquiden $\mathrm{y}$ paguen las deudas $\mathrm{y}$ obligaciones pendientes a la fecha del acuerdo, a no ser que la compañía obtuviera el consentimiento previo de los acreedores. Agrega que, para ejecutar este artículo, los administradores presentarán al juez o tribunal un inventario en que se aprecien los valores en garantía al tipo medio de cotización del último trimestre y los inmuebles por la capitalización de sus productos según el interés legal del dinero.

De lo expuesto se desprende que la legislación chilena aparentemente incompleta deja todo al criterio de la Superintendencia de Sociedades Anónimas; y que la nuestra resulta de difícil aplicación ya que por lo común los administradores no se sienten calificados para determinar si el capital efectivo restante excede en un $75 \%$ de las deudas, en otros casos, les re. sulta imposible obtener consentimiento expreso de los acreedores y casi nunca los accionistas quieren someterse a todo un procedimiento judicial moroso y complicado.

Tampoco se pone nuestro Código en el caso de reducción por pér. dida de capital.

Los sistemas de Suiza y España parecen más claros y precisos, pero, en nuestro concepto, el mejor es el Suizo por exigir que la reducción se haga a base del informe de auditores calificados $y$ por cuanto permite la reducción sin avisos ni otras formalidades en los casos de pérdida efectiva de capital, esto es cuando los acreedores no pueden ser perjudicados por la reducción que tiene solo por objeto comprobar un hecho consumado.

D) Los accionistas deben cumplir su empeño.

El Código de Comercio chileno en el artículo 446 obliga al socio industrial a cumplir su empeño, lo que es evidente, pues en tal caso los servicios correspondientes tienen que ser considerados como un aporte a la sociedad que faculta al accionista para recibir las acciones correspondientes.

No rige, desde luego, este principio para los países en que no se acepta aportes de industria a cambio de acciones.

\section{Derechos de los accionistas}

Los derechos de los accionistas pueden resumirse bajo once títulos principales o sea:

A) A ser reconocidos como socios;

B) A transferir sus acciones;

C) A convocar a las juntas;

D) $\bar{A}$ concurrir $a$ ellas y $\alpha$ votar:

E) A elegir administradores;

F) A examinar las cuentas y solicitar informes; 

G) A percibir dividendos;
H) A participar en el producto de la liquidación;
I) A participar en las nuevas emisiones;
J) A gozar de las preferencias que se les hayan otorgado; $y$
K) A impugnar los actos o acuerdos indebidos.

\section{A). Derecho de ser reconocidos como socios.}

En Suiza (art. 646) y en España (art. 39) la ley declara expresamente que la acción confiere a su tenedor la condición de socio. No se pronuncian en esta forma expresa la legislación chilena, ni la peruana.

Aún cuando se trata de un hecho evidente $\mathrm{y}$ de un derecho indiscutible, es conveniente que lo deciare la ley, for el carácter fundamental que reviste. Por eso en Suiza la ley lo reconoce como un derecho adquirido del cual no pueden ser privados los interesados sin su asentimiento, o sea que en ésto no podrán ser obligados por la mayoría de los accionistas.

En virtud de ello tampoco podrá una mayoría de accionistas expulsar $\alpha$ otros de la sociedad.

\section{B) Derecho de convocar a las Juntas.}

Normalmente los estatutos reglamentan la forma de convocar a las juntas; $y$. por lo general, el precepto se cumple sin dificultades, pero puede ocurrir que los administradores no hagan las convocatorias dentro de los plazos $y$ en los casos determinados por los estatutos y cuando resulte indispensable para la buena marcha de la sociedad.

Inclusive puede suceder que los administradores posterguen las convocatorias para impedir que se descubra algún fraude que ellos encubran - pretendan encubrir.

Por eso la mayoría de las legislaciones confiere a un nümero determinado de ciccionistas el derecho de convocar $\alpha$ junta $Y$ en tal caso la autoridad respectiva practica la citación a solicitud de los interesados siempre que se le exprese el objeto de la reunión.

En España, seqún los artículos 56 y 57 de lo ley, los administradores deberón convocar a la junta cuando lo solicite un número de sccios que represente a lo menos la décima parte del capital desembolsado, expresando en la solicitud los asuntos a tratar en la junta $y$, en este caso, la junta deberá ser convocada para celebrarse en los 30 días siguientes a la fecha en que se hubiera requerido notarialmente a los administradores para convocarla, debiendo incluirse, necescriamente, en la orden del día, los cisuntos que hubieran sido objeto de la solicitud.

Si la junta ordinaria no fuera convocada dentro del plazo legal, podrá serlo a petición de los socios y con audiencia de los administradores por el Juez de Primera Instancia del domicilio social quien, además designará la persona que habrá de presidirla.

En Suiza, el artículo 699 del Código de las Obligaciones dispone que uno o mós accionistas que representen en conjunto por lo menos la décima 
parte del capital social, puede requerir la convocatoria de la asamblea general, haciéndolo por escrito e indicando el fin que se persigue.

Si la administración no accede a la junta dentro de un plazo convenido, el Juez ordena la convocatoria a petición de los solicitantes.

En el Perú no existe disposición sobre la materia, resultando casi imposible ejercitar este derecho. No pocas veces se originan juicios largos y costosos y, a pesar de ellos, se burla a los accionistas, pues, mientras dura el litigio no existe posibjlidad de hacer efectivas las responsabilidades a que haya lugar.

La legislación española es clara y precisa, pero, al disponer que el Juez cite a junta con audiencia de la administración, evidentemente abre las puertas para toda clase de dilaciones; $\mathrm{y}$, además, al señalar un plazo de 30 días para la reunión, dá la opción para maniobras indebidas. Muchas veces la reunión de una junta es asunto de urgencia y 30 días pueden resultar un plazo excesivo. Por eso estamos de acuerdo con la legislación Suiza que permite reunir la junta dentro de un plazo conveniente y no requiere oir previamente $\alpha$ los administradores.

Se justifica esto por tratarse del ejercicio de un derecho incuestionable.

Desde luego que corresponderá al criterio del Juez rechazar las peticiones maliciosas o que constituyen por si solas un abuso del derecho.

\section{C) Derecho de transferir sus acciones.}

La facultad que tiene el accionista de ceder sus acciones a tercera persona es inherente a su derecho de propiedad sobre las mismas.

La legislación mercantil chilena no contiene declaración expresa acer. ca de esta materia, salvo la prohibición de enajenar durante 2 años las acciones que $\alpha$ título de remuneración se entreguen $\alpha$ los fundadores o por aportes en natura (art. 95 del Decreto $N^{\circ}$ 251).

La ley española, como hemos visto anteriormente, establece tácitamente la trasmisibilidad, pero permite, en el artículo 46, que los Estatutos impongan ciertas limitaciones. Además, en el artículo 14 prohibe transferir las acciones mientras la sociedad no está inscrita en el Registro Mercantil.

En Suiza, se reconoce el derecho de ceder las acciones, pero el artículo 686 ya citado, permite limitar el derecho de libre trasmisión, por motivos previstos en los estatutos y aún pactar que se podrá rechazar la inscripción de la trasmisión sin expresión de causa.

Nuestro Código de Comercio no se pronuncia sobre el particular. Sólo el crí́culo 851 del Código Civil dice de un modo general que no se puede establecer la prohibición de enajenar salvo los casos permitidos por la ley.

Por nuestra parte consideramos que el derecho de libre trasmisión de las acciones debe ser expresamente proclamado por la ley al tratar de esta clase de sociedades, tanto por ser ellas predominantemente aurupaciones de capitales, cuanto por su carócter anónimo, condiciones ambas que excluyen toda vinculación personal indisoluble, y que no permiten retener $a$ un socio en la sociedad contra su voluntad si puede apartarse de ella sin retirar su capital, cediendo a otro sus acciones. Por lo mismo, tambión 
como hemos expresado anteriormente, al tratar sobre la definición de la institución, debe restringirse y reglamentarse muy cuidadosamente los pactos que limitan este derecho.

\section{D) Derecho de concurrir a las juntas $y$ votar en ellas.}

\section{a) Generalidades.}

El recurso principal que tienen los accionistas que no forman parte de la administración - - a veces todo poderosa - de una sociedad anónima, para hacer efectivos sus derechos y conocer cómo se manejan sus intereses es concurrir a las juntas de accionistas y votar en ellas.

Además, es en tales juntas que se identifican periódicamente la persona jurídica - creación artificial, al fin y al cabo- con las personas humanas ciue le dan vida y existencia real.

Por eso el respectivo derecho no puede serles negado, aunque a veces se permita restringirlo.

\section{b) Las cuatro legislaciones.}

El Código de Comercio de Chile no contiene declaración expresa sobre el punto; pero el artículo 24 de su Reglamento reconoce el derecho de concurrir y votar prescribiendo que solamente votarán en las juntas generales los accionistas que figuren en el registro social y los tenedores de acciones al portador anotados oportunamente en la oficina de la sociedad.

En España, la ley, en sus artículos 38, 39, 48 y 49 se refiere en diversas formas al derecho de que tratamos; impide exagerarlo, al prohibir el voto plural (aunque puede emitirse las acciones por series atribuyendo a cada serie distinto derecho); pero permite limitarlo, tanto al declarar que podrá exigirse la posesión de un número mínimo de títulos para ejercitarlo (esto no significa privar del derecho $\alpha$ voto $\alpha$ quienes no llegan a tener el número mínimo de títulos ya que pueden acumular sus acciones con otros accionistas y concurrir por medio de un representante común que ejerza el derecho de voto en proporción al número de acciones que posean); cuanto al dar autorización para que se fije el número máximo de votos que un mismo accionista puede emitir.

La ley española priva, así mismo, del derecho de votar, al accicnista que se hallare en mora en el pago de sus dividendos pasivos; $y$ declara extinguido el derecho cuando las acciones hayan sido reembolsadas por la sociedad, salvo disposición en contrario de los estatutos.

El Código Suizo de Obligaciones, en el artículo 646, declara expresamente que los accionistas, sin su consentimiento, no pueden ser privados do sus derechos adquiridos entre los que menciona el de participar en las juntas $y$ el de votar en ellas.

Permite así, indudablemente, las restricciones si son aceptadas por las portes.

Esto se ratifica en el artículo 689, que se refiere $\alpha$ "las accionistas que tienen derecho de voto", en el artículo 691 que prohibe las maniobras 
destinadas a hacer ilusorias las restricciones estatutarias $y$ en el artículo 692 que permite limitar el número de votos del tenedor de varias acciones.

Sin embargo, el mismo artículo 692, declara que todo accionista tiene, por lo menos, derecho a un voto; lo cual significa poner un tope a las limitaciones.

Según el artículo 692, los accionistas deben ejercer su derecho a voto en proporción al valor nominal de todas las acciones que posean; pero el -artículo 693 permite conceder preferencias otorgando el derecho de voto en proporción al número de acciones que tenga el accionista y con prescindencia del monto de su capital, de modo que puedan establecerse importantes diferencias entre los socios.

Contiene, también, el Código Suizo, en el artículo 691, una disposición de sumo interés que permite excluir a los falsos accionistas y al que pretenda intervenir ilícitamente en las juntas.

En cuanto al Código de Comercio del Perú, no legisla expresamente sobre estas cuestiones, limitóndose a decir, en el artículo 159, que en la escritura de constitución debe constar la sumisión al voto de la mayoría de la junta de socios, debidamente convocada y constituída en los asuntos propios de su deliberación; y el modo de contar y constituirse la mayoría.

c) Crítica.

De la comparación de las cuatro legislaciones de que tratamos resulta que la nuestra es la más incompleta, pues por dejar todo a la voluntad de las partes, cae en la imprevisión y permite por lo tanto el abuso o las interpretaciones arbitrarias.

Resalta, en cambio, la prudencia y el equilibrio de las leyes de España y Suiza que cubren el punto en todos sus aspectos, reconociendo a los accionistas el derecho de concurrir y votar y definiendo claramente, al mismo tiempo, las restricciones que puedan imponerse a tales derechos $y$ los límites de las mismas.

\section{E) Derecho de elegir administradores.}

\section{a) Generalidades.}

Anexo al derecho de concurrir a las juntas de accionistas y votar en ellas, es el de elegir en tales juntas los administradores de la sociedad. en cuanto tal acto sea de competencia de las mismas.

Si bien, dentro del artificio que significa la personalidad jurídica de la sociedad, los administadores son representantes del ente social autónomo, distinto de los asociados, en realidad, al manejar los negocios comunes, lo que tienen $\alpha$ su cargo es el patrimonio de los accionistas.

No puede, por lo tanto, de un modo general, negarse a éstos el derecho de nombrar a quienes, en esencia, a través de la sociedad cuidan también de sus intereses y los representan sobre todo cuando, por lo general, los Directorios, Juntas o Consejos de Administración, son casi omnipo. tentes y en el fondo son los únicos que conocen exactamente el estado de los negocios y los que imprimen el curso feliz o desgraciado a las actividodes sociales. 
b) Las cuatro legislaciones.

El Código de Comercio de Chile dice, en su artículo 451, que la so ciedad anónima es administrada por mandatarios temporales revocables, sean o no socios, elegidos en la forma que prevengan los estatutos de la sociedad; $y$ en el artículo 466 agrega que la asomblea general de accionistas se reunirá en épocas fijas para examinar la situación de la sociedad y revocar o confirmar el nombramiento del gerente. El artículo 97 del reglamento con fuerza de ley, que crea la Superintendencia de Sociedades Anónimas, completa el cuadro, disponiendo que todas las elecciones que se efectúen en las juntas de accionistas se harán por voto unipersonal, esto es votando los accionistas por una sola persona al mismo tiempo, aunque se permite proceder en sentido diferente cuando haya acuerdo unánime o varias clases de acciones.

En España, el artículo 71 de la ley dispone expresamente que el nom. bramiento de los administradores y la determinación de su número, cuando los estatutos establezcan solamente el máximun y el mínimo, corresponde a la junta general. El mismo artículo agrega que la elección se hará por medio de votación $\mathrm{y}$ permite la acumulación de votos para designar uno - más directores.

En Suiza, el artículo 708 del Código de Obligaciones manda también que los administradores sean elegidos por la asamblea general.

Custodiando el interés de las minorías y de los accionistas de diversas clases, en su párrafo final dispone que si hay varios grupos de accio nistas, cuya situación jurídica sea diferente, los estatutos asegurarán a cada uno de ellos lá elección de un representante, por lo menos, en la administración; y que los grupos importantes tienen, del mismo modo, el derecho de estar representados en el comité que se constituya en el seno del Consejo de Administración.

El Código de Comercio del Perú, en su artículo 159 expresa que en la escritura social de la compañía anónima deberá constar la designación de la persona o personas que habrán de ejercer la administración y el modo de proveer las vacantes; y el artículo 163 reconoce el derecho de los accionistas a nombrar administradores indicando que estos últimos serán designados por los socios en la forma que determinen su escritura social y estatutos o reglamento.

\section{c) Crítica.}

Nuestro Código contiene, así, en esencia, los principios concernientes al derecho de que tratamos; sólo le faltan las previsoras disposiciones de 10 ley de España y sobre todo del Código Suizo, concernientes a la proteccí́n de las minorías y a la defensa de los grupos representctivos de accionistas.

F) Derecho de excminar las cuentas y de solicitar informes.

a) Generalidades.

Otra consecuencia de la calidad de socio y del derecho de concurir a las juntas, es la facultad que tienen los accionistas de examinar las cuentas y de solicitar informes respecto de los asuntos que se traten en las juntas. 
Solo asi pueden conocer si sus intereses están bien o mal administrados y pronunciarse sobre las mociones que se sometan a su consideración.

\section{b) Las cuatro legislaciones.}

El artículo 21 del Reglamento de Sociedades Anónimas de Chile indica que durante los ocho días onteriores a la junta general ordinaria, la memoria Y balance que debe presentar el Directorio, estarán a la disposición de los accionistas. Para este objeto la sociedad debe tener en su oficina copias impresas o escritas a máquina de esos documentos. La memoria y balance deberón remitirse por correo a los accionistas que tengan registrado su domicilio en la sociedad, con diez días de anticipación, a lo menos, a la fecha fijada para la junta ordinaria.

Sin embargo, la Superintendencia de Sociedades Anónimas puede autorizar a aquellas sociedades que tengan un gran número de accionistas, para limitar el envío de dichos documentos a aquellos accionistas que tengan un número de acciones superior a un mínimum determinado.

Agrega el mismo artículo que la memoria que presente el directorio a la junta ordinaria de accionistas deberá contener una información explicativa $y$ razonada sobre las operaciones realizadas durante el ejercicio; $\bar{Y}$ que en la cuenta de ganancias $Y$ pérdidas del balance se colocarán en rubro separado todas las sumas percibidas durante el ejercicio por el Presidente $\mathrm{y}$ los Directores sean como remuneración por su calidad de tales, dieta por asistencia a sesiones, participación en las utilidades, sueldos u honorarios aue les hayan correspondido por su calidad de empleados, técnicos o profesionales, gratificaciones, viáticos, o estipendios extraordinarios de cualquier clase.

La ley española trata de este derecho en los artículos 65, 66, 108, 109 y 110 que establecen los siguientes principios:

(1) Los accionistas podrán solicitar por escrito, con anterioridad a la reunión de la junta, o verbalmente durante la misma, los informes o aclaraciones que estimen precisos acerca de los puntos comprendidos en el orden del día. Los administradores estarán obligados a proporcionárselos, salvo en los casos en que, a juicio del Presidente la publicidad de los datos solicitados perjudique los intereses sociales. Esta excepción no procederá cuando ìa solicitud esté apoyada por accionistas que representen al menos la cuarta parte del capital desembolsado.

(2) Cualquier accionista de la sociedad y las personas que hubieren asistido a la junta en representación de los accionistas no asistentes podrán obtener certificación de los acuerdos adoptados.

(3) El balance, la cuenta de pérdidas y ganancias, la propuesta sobre distrîbución de los beneficios y la memoria deberón ser sometidas al examen e informe de los accionistas censores de cuentas quienes por escrito propondrán su aprobación o formularón los reparos que estimen convenientes, en el plazo máximo de un mes. Para realizar esta labor, los censores podrán examinar por sí o en unión de personas técnicas la contabilidad y todos los antecedentes con la mayor amplitud, $y$ sin que ni unos ni otros pue- 
dan revelar particularmente a los demás accionistas o a terceros el resultado de sus investigaciones. Los administradores sólo podrán limitar el derecho de examen de los censores en caso de excepcional importancia, cuando así lo exija el interés social gravemente comprometido.

Los censores podrán representar a la mayoría y a la minoría y su informe, salvo pronunciamiento expreso de la junta general en contrario, sólo habrá de referirse a la exactitud y veracidad de los datos consignados en el balance y cuenta de pérdidas y ganancias y a los criterios de valoración y de amortización seguidos en el ejercicio por la sociedad.

(4) Con carácter excepcional, y a solicitud de accionistas que representen por lo menos la tercera parte del capital social desembolsado, los censores deberán realizar en cualquier momento una investigación extraordinaria para aclarar los extremos o anomalías que sean sometidos a su examen.

(5) El balance, la cuenta de pérdidas y ganancias, la propuesta sobre distribución de los beneficios y la memoria, junto con el informe de los censores, se pondrán por el Consejo de Administración a disposición de los accionistas, en el domicilio social, 15 días antes de la celebración de la junta general.

La aprobación de estos documentos por la junta no significa el descargo de los administradores por la responsabilidad en que pudieran haber incurrido.

El Código Suizo regula también esta cuestión aunque con menos am. plitud que la legislación española, más generosa en materia de informes, en sus artículos 696 y 697 cuyos principios esenciales son los siguientes:

(1) La cuenta de pérdidas y ganancias y el balance así como el informe de los controladores, la memoria de la gestión y las proposiciones concernientes al empleo de las utilidades netas, deben ser puestas a disposición de los accionistas en la sede del estabecimiento principal de la socie. dad y de sus sucursales por lo menos 10 días antes de la reunión de la Ascomblea general ordinaria.

(2) La cuenta de ganancias y pérdidas, el balance y la memoria de la gestión permanecen a disposición de los accionistas durante un año.

(3) Cada accionista tiene la facultad de hacerse expedir, a cuenta de la sociedad, una copia del balance, así como la cuenta de ganancias y pérdidas.

(4) Los tenedores de acciones al portador son informados por una publicación que se hace en la Hoja Oficial Suiza de Comercio y además en la forma que prevean los estatutos.

(5) Los titulares de acciones nominativas inscritos en el Registro de Acciones deben recibir una comunicación especial sobre el particular.

(6) Los accionistas tienen el derecho de llamar la atención de los controladores sobre las valuaciones dudosas y de reclamar las explicaciones necesarias sobre ellas.

(7) Los accionistas no pueden examinar los libros ni la correspondencia sino en virtud de una autorización expresa de la asamblea general o de una decisión de la administración y a condición de que no se comprometa el secreto de los negocios, 
(8) El juez competente puede obligar a Ia sociedad a dar informes a los accionistas, por medio de extractos certificados conformes de sus libros - de su correspondencia, sobre los hechos precisos que tienen importancia para el ejercicio del derecho de control. Las decisiones del juez no pueden comprometer los intereses de la sociedad.

(9) El derecho de control de los accionistas no puede ser suprimido ni restringido por los estatutos ni por decisión alguna de un órgano social.

Nuestro Código de Comercio sólo contiene dos principios, en los artículos 166 y 180.

Según el primero los socios y accionistas de las compañías anónimas no pueden examinar la administración social, ni hacer investigación alguna respecto a ella, sino en las épocas y en la forma que prescriban sus estatutos $\mathrm{y}$ reglamentos.

De acuerdo con la segunda, los gerentes o administradores de las compañías mercantiles no pueden negar a los socios el examen de los documentos y comprobantes de los balances que se formen para manifestar el estado de la administración social, salvo lo prescrito en el artículo 166, lo que equivale a decir que pueden negar a los socios el examen de todos los do. cumentos y comprobantes de los balances que se formen para manifestar el estado de la administración social, si no se los piden en las épocas y en la forma que prescriban sus estatutos y reglamentos.

\section{c) Crítica.}

La comparación de nuestro Código con las legislaciones de Chile, España y Suiza da un resultado verdaderamente desolador para la legislación nacional, pues mientras que se ve que en otros países el derecho de examinar las cuentas y de solicitar informes está debidamente cautelado puede afirmarse sin exageración que en el Perú prácticamente no existe porque ello queda entregado a lo que prescriban los estatutos y reglamentos de cada sociedad, esto es a la voluntad de las partes, que por lo general es solo la de la mayoría.

No es raro así que entre nosotros sea con frecuencia imposible obtener a tíempo y en debida forma los balances de las sociedades anónimas, sus memorias, los documentos comprobativos o informes sobre las operaciones sociales.

Inspirándonos en las modernas legislaciones de Suiza y España, que, sin entregar al público los secretos comerciales ni permitir excesos que violen la reserva de los negocios de toda sociedad, podríamos dar a quienes invierten su dinero en sociedades conónimas en el país, las garantías indispensables de que deben gozar en esta materia.

(G) Derecho de percibir dividendos.

\section{a) Generalidades.}

Siendo las sociedades anónimas agrupaciones de capitales, 0 , en otras palabras, entidades destinadas a producir lucro a los accionistas, otro derecho fundamental de éstos es el de percibir dividendos, del cual no pueden ser despojados. 


\section{b) Las cuatro legislaciones.}

Las leyes chilenas reconocen debidamente el derecho del accionista de percibir dividendos y lo reglamentơn en el artículo 463 del Código de Comercio y en los artículos 106, 107 y 108 del decreto con fuerza de ley sobre compañías de seguros, sociedades anónimas y bolsas de comercio, siendo sus principios esenciales los siguientes:

(1) Las sociedades anónimas destinarán de las utilidades de cada ejercicio una cuota no inferior al $5 \%$ de ellas para formar un fondo de reserva legal, cuyo monto será igual, a lo menos, al $20 \%$ del capital social.

(2) Es prohibida la repartición de dividendos antes de completarse el fondo de reserva salvo el caso de que se haya destinado a éste la cuota mínima de las utilidades que prescribe la ley o la que determinen los estatutos.

(3) El saldo de las utilidades líquidas, descontada la cuota que se destine para fondos especiales, que no podrá ser superior al $30 \%$ de ellas, se distribuirá como dividendo entre los accionistas a prorrata de sus accio. nes, salvo que la escritura social disponga otra cosa.

En España, el artículo 39 de la ley declara expresamente que la acción confiere a su titular legítimo el derecho de participar en el reparto de la ganancia y los artículos 50 y 102 establecen la obligación de los ad. ministradores de proponer anualmente la distribución de las utilidades obtenidas en el ejercicio pero no es tan precisa como la ley chilena que obliga a distribuir dividendos después de haberse destinado la parte correspondiente a fondos de reserva $y$ otras inversiones especiales, salvo disposición en contrario de la escritura social.

En Suiza, el artículo 646, ya citado anteriormente, dispone que los accionistas no pueden ser privados, sin su consentimiento, de sus derechos adquiridos, entre los que figura el derecho a los dividendos; $y$ este artículo está corroborado por el 660 que declara expresamente que cada accionista tiene derecho a una parte proporcional del beneficio neto por repartir entre los accionistas de acuerdo con los términos de la ley o de sus estatutos.

En nuestro Código no existe disposición alguna sobre la materia. Tenemos que atenernos por lo tanto solo al artículo 124 que, al definir el contrato de compañía, dice que por él dos o más personas se obligan a poner en fondo común, bienes, industrias, o alguna de esas cosas, para obtener lucro.

\section{c) Crítica.}

Nuevamente hay que lamentar en este punto la falta de reglamentación de nuestra ley que no cautela un derecho tan elemental.

Las leyes de Chile, España y Suiza pueden servirnos de buen ejemplo sobre el particular. 


\section{H) Derecho a participar en el producto de la liquidación.}

\section{a) Generalidades.}

El segundo derecho, de naturaleza económica, de los accionistas de toda sociedad anónima, es el de participar en el producto de la liquidación de la sociedad.

No hay nada más natural que, si ésta descparece, se les devuelva el capital y que se les entregue su participación en cualquier remanente, después de pagadas o de asegurado el pago de las deudas sociales.

Nadie les puede negar su derecho a recuperar su capital, una vez pagados los acreedores; y si hubiere un sobrante esto constituye utilidades sujetas a las reglas examinadas en los párrafos precedentes.

\section{b) Las cuatro legislaciones.} recho.

Las leyes chilenas no contienen disposición especial sobre este de-

En cambio, la ley española, en el inciso 1 del artículo 39, ya citado, declara expresamente que la acción confiere a su titular el derecho de participar en el patrimonio resultante de la liquidación; y en el artículo 162 reglamenta cuidadosamente la forma de hacer la división del haber social disponiendo que el activo resultante después de satisfacer los créditos contra la sociedad se repartirá entre los socios en la forma prevista en los estatutos o, en su defecto, en proporción al importe nominal de las acciones.

Si todas las acciones no se hubieren liberado en la misma proporción, dispone la ley española que se restituirá en primer término a los accionistas que hubieren desembolsado mayores cantidades el exceso sobre la aporiación del que hubiere desembolsado menos $\mathrm{y}$ el resto se distribuiró entre los accionistas en proporción al importe nominal de sus acciones.

Deciara que, desde luego, en la misma proporción sufrirón las eventuales pérdidas en el caso de que el activo no bastase para reembolsarles las aportacicnes hechas.

En Suiza, nuevamente, el artículo 646, relativo a la protección de los derechos adquiridos, incluye entre ellos el derecho de los accionistas a su parte en la liquidación del patrimonio social.

En el Perú, el artículo 225 del Código de Comercio declara que, terminada la liquidación y llegado el caso de proceder a la división del haber social, según la liquidación que hicieren los liquidadores o la junta de socios, que cualquiera de ellos podrá exigir que se celebre para este efecto, los mismos liquidadores verificarón dicha división dentro del término que la junta determine.

c) Crítica.

La legislación peruana, reconoce, por lo expuesto, el derecho de los accionistas de participar en el producto de la liquidación de los bienes de la sociedad. Sólo le falta ampliarlo estableciendo los principios conforme a los cuales se hará la división, tal como lo hace el artículo 162 de la ley española. 
I) Derecho a participar en las nuevas emisiones de acciones que haga la sociedad.

\section{a) Generalidades.}

Los miembros de una sociedad anónima tienen particular interés en participar en las nuevas emisiones que haga normalmente la sociedad, por cuanto, si no tomaran parte en ellas, disminuiría proporcialmente su parlicipación en el activo social y también su proporción en el derecho $\alpha$ voto en las juntas de accionistas con los consiguientes efectos patrimoniales $Y$ administrativos.

De un lado se recortaría su participación en los dividendos $y$ en la distribución del activo social $\mathrm{y}$ de otro lado les sería más difícil influir en las votaciones de las juntas de accionistas así como en el nombramiento de administradores $y$ en las demás decisiones de la sociedad.

b) Las cuatro legislaciones. particular.

La legislación chilena no contiene disposiciones expresas sobre el

En España, el inciso $2^{\circ}$ del artículo 39 reconoce expresamente este derecho al titular legítimo de toda acción; principio que es corroborado por el artículo 92 según el cual en toda elevación de capital con emisión de nuevas acciones, los antiguos accionistas podrán ejercitar, dentro del plazo que a este efecto les conceda la administración de la sociedad, y que no será inferior a un mes, el derecho a suscribir en la nueva emisión un número de acciones proporcionado al de las que posean.

En Suiza, el crtículo 652 del Código de Obligaciones dispone que, salvo disposición en contrario de los estatutos o de la decisión que acuerde el aumento de capital, cada asociado tiene el derecho de suscribir una fracción de los nuevos títulos que esté en proporción con el número de sus acciones. particular.

Entre nosotros, el Código de Comercio no ha previsto nada sobre el

c) Crítica.

Del examen de estas legislaciones resalta, sin duda, que en nuestra: legislación no hay protección alguna para el accionista en la materia de que tratamos y que es urgente legislar sobre el particular, pues el accionista en minoría se encuentra abandonado a la voluntad de la moyoría y a las maniobras abusivas o dolosas de los administradores cuando éstos actúan sólo para su provecho particular.

J) El derecho de gozar de las preferencias que les hayan sido concedidas.

\section{a) Generalidades.}

A pesar de que, en principio, todos los accionistas de una sociedad anónima deberían gozar de los mismos derechos y obligaciones, la práctica y la legislación universal reconocen la posibilidad de que Ias sociedades: 
de esta clase emitan acciones de diversa categoría y que unas confieran más o menos derechos que otras, esto es que existan acciones comunes y acciones privilegiadas llamadas también preferenciales o preferidas.

Generalmente se emite esta clase de acciones cuando la sociedad, por alguna circunstancia, necesita procurarse mayor capital que no podría con. seguir mediante la emisión de acciones iguales a las ya existentes.

Hay, sin embargo, un límite natural para ello y es que las ventajas concedidas a las acciones privilegiadas no pueden ser de magnitud y extensión tales que priven al accionista común de todo derecho, pues ello no sería ya un derecho de preferencia sino un derecho de abuso que ninguna ley puede reconocer.

Se admiten también otras limitaciones a este derecho, según lo dispongan las leyes de cada país o los estatutos de las sociedades; pero el hecho es que, una vez emitidas las acciones preferidas, dentro de los marcos legales o estatutarios, sus tenedores han de ser respetados en el ejercicio de los derechos que ellas les confieran.

b) Las cuatro legislaciones.

El decreto con fuerza de ley $\mathrm{N}^{\circ} 251$ permite, en Chile, la emisión de acciones preferidas, las que pueden conferir los siguientes derechos:

(1) De que con las utilidades anuales se pague a los tenedores un interés preferente sobre su valor nominal (art. 104).

(2) De que este derecho sea acumulativo, esto es, que si la sociedad no tuviere utilidades suficientes en un año, los intereses que no puedan pagarse en tal año lo sean con las utilidades del año o años siguientes (art. 105).

(3) De que al liquidarse la sociedad se pague preferentemente el valor del aporte representado por ellas y los intereses devengados y no pagados sobre las mismas (art. 105).

(4) De que los tenedores de estas acciones puedan también tener derecho a un mayor o menor número de votos en las asambleas de accionistas según lo establezcan los estatutos sociales, (art. 104).

(5) Las demás preferencias que contemplen los estatutos y que acepte Ia Superintendencia de Sociedades Anónimas (art. 105).

En España, el artículo 37 de la ley establece que podrán existir distintas clases o series de acciones; $y$ en el mismo artículo 37 así como en los artículos 38,85 y 93 reglamentan el respectivo derecho estableciendo los principios siguientes:

(1) La diferencia entre Ias acciones puede consistir en el valor nominal, en el contenido de derechos o en ambas cosas a la vez, pero las acciones de la misma serie o clase serón siempre de igual valor y conferirán los mismos derechos (art. 37).

(2) En ningún caso seró lícita la creación de acciones de voto plural, pero los estatutos podrán exigir, con carácter general, a todas las acciones, cualquiera que fuere su clase o serie, la posesión de un número mínimo de sítulos para asistir a la junta general y ejercitar en ella el derecho de voto $\ominus$ igualmente podrớn fijar el número máximo de votos que un mismo accio. nista puede emitir (art. 38). 
(3) Para ejercitar el derecho de voto será lícita la agrupación de cecio. nes (art. 38).

(4) Ninguna modificación de los estautos que implique nuevas obligaciones para los accionistas podró adoptarse sin la aquiesencia de los interesados (art. 85).

(5) Cuando la modificación afecte directa o indirectamente a los derechos de una clase especial de acciones será preciso, además, el acuerdo de Ia mayoría de estas acciones, adoptado con los requisitos previstos por ia ley para llevar a cabo cualquier modificación de los estatutos (art. 85).

(6) Cuando la modificación consista en restringir o condicionar la tras. misibilidad de las acciones nominativas, los accionistas afectados que no hayan voicido a favor de tal acuerdo no quedarán sometidos a él durante un plazo de tres meses, contados descie su inscripción en el Registro Mercantil (art. 85).

(7) Aunque los estatutos no lo hayan previsto, la junta ceneral podrá ccordar, con los requisitos que expresa el artículo 84 , relativo a la modificación de estatutos, la creación de acciones preferentes o la transformación de acciones ordinarias en preferentes, con los derechos que el acuerdo determine (art. 93).

(8) Cuando existan acciones preferentes será menester observar lo indicado en el inciso 5, para crear otras de la misma clase que aiecten a los derechos de las antiguas (art. 93).

En Suiza el artículo 654 del Código de Obligaciones declara que la asamblea general puede, en virtud de una cláusula o de una modificación de los estatutos, decidir la emisión de acciones privilegiadas o la conversión. de antiguos títulos en acciones privilegiadas.

Estas acciones privilegiadas gozan, según el artículo 656, de las ventajas que les hayan sido expresamente conferidas, en relación con las acciones ordinarias, por los estatutos primitivos o como consecuencia de una modificación de los mismos. En lo demás están asimiladas a las acciones ordinaricss.

Los ventajas pueden referirse, especialmente, según el mismo artículo: 656, a los dividendos, al derecho a participar o no en los dividendos suplementarios, a la participación en la liquidación y al derecho preferente de suscribir acciones en caso de emisiones futuras.

Si existen ya acciones privilegiadas, no pueden emitirse nuevas accia nes con preferencia sobre ellas, sino con la aprobación de una asamblea especial de los accionistas (pudiendo o no pudiendo) afectados $y$ de una asamblea general de todos los accionistas, pudiendo establecerse en los estatutos disposición en contrario.

Estas reglas son aplicables también en caso de modificación o de supresión de los derechos de prioridad que los estatutos acuerden a las accio. nes privilegiadas (art. 654).

Así mismo, salvo disposición en contrario, según el artículo 655, la emisión de acciones privilegiadas y la modificación o la supresión de los derechas de prioridad de las mismas no pueden decidirse sino en una asamblea general en que estén representados por lo menos los dos tercios de todas las acciones. 
Contrastando con el detalle y cuidado que toman las legislaciones de Chile, España y Suiza para reglamentar esie derecho, nuestro Código de Comercio no contiene disposición alguna sobre el particular.

c) Crítica.

La necesidad de reformar nuestra ley en este aspecto se impone sin necesidad de mayor comentario. En cuestión tan delicada como la emisión, derechos, ventajas y limitaciones de las acciones privilegiadas, la ley no puede guardar silencio. Precisa que contenga disposiciones claras sobre el particular para evitar que se atropelle tanto los derechos de los accionistas comunes cuanto de los preferenciales.

K) Derecho de impugnar los actos o derechos indebidos de la administración o de otros accionistas.

\section{a) Generalidades.}

Como consecuencia del principio según el cual la ley no ampara el abuso del derecho y también como medio de impedir que las mayorías aprovechando de su poder cometan excesos en perjuicio de los demás accionistas, las legislaciones de diversos países, desde fines del siglo pasado, reconocen a los posibles damnificados el derecho de impugnación, en virtud del cual pueden objetar las decisiones ilegales o contrarias a los estatutos sociales.

\section{b) Las cuatro legislaciones.}

Las leyes mercantiles de Chile no contienen disposición expresa sobre la maieria de modo que en este país habrá que recurrir, para defender el derecho de impugnación, seguramente, a los principios generales.

En España, en cambio, los artículos 67, 68, 69 y 70 estatuyen cuidadosa y detalladamente sobre el particular.

Según ellos pueden ser impugnados:

(1) Los actos contrarios a la ley.

(2) Los acuerdos sociales que se opongan a los estatutos.

(3) Los acuerdos que, adoptados en beneficio de uno o varios accio nistas, lesionen intereses de la sociedad.

Este derecho de impugnación tiene dos límites: el primero en cuanto se refiere a las personas, pues no afecta a los derechos adquiridos de buena fe por los terceros, a consecuencia del acuerdo impugnado (artículo 67 in-fine); $y$, el segundo en cuonto al tiempo, pues, de acuerdo con el artículo 68, la acción de impugnación de los acuerdos objetables deberá ejerciturse en el plazo de 40 días, a partir de la fecha de los mismos. O, si estos fueran objeto de inscripción en el Registro, dentro del mes siguiente a la fecha en que la inscripción tenga lugar. No quedon sometidas a estos plazos de caducidad las acciones de nulidad de los acuerdos contrarios a la ley, que podrón ejercitarse pasados esos plazos por procedimiento de juicio declara. tivo ordinario (art. 68 in-fine). 
Pueden intentar la acción, de acuerdo con el artículo 69, los concurrentes a la junta que hubiesen hecho constar en el acta su oposición al acuerdo impugnado, los accionistas ausentes y los que hayan sido ilegítimamente privados de emitir su voto. El procedimiento de impugnación se dirige contra la sociedad (inciso $5^{\circ}$ del artículo 70) y se tramita ante el Poder Judicial en forma sumarísima (art. 70).

A solicitud del demandante o demandantes que representen al menos la quinta parte del capital social, podrá el Juez, al tiempo de proveer sobre la admisión de la demanda, suspender el acuerdo impugnado, oídos los representantes de la sociedad, quienes podrán solicitar, $\alpha$ su vez, que se ase. guren, mediante caución, los eventuales perjuicios que con la suspensión puedan irrogarse a la sociedad (artículo 70, inciso 4\%).

Naturalmente, la ley prevé el caso de demoras, procedimientos o impugnaciones de mala fe $y$ en el inciso 11 del artículo 70 dispone que las costas del proceso de impugnación se impondrán por ministerio de la ley al litigante o litigantes vencidos, si la demanda se estimase totalmente o fuese desestimada en su integridad; que, en los demás supuestos, el Tribunal determinará la proporción en que han de ser satisfechas las que tengan carácter común y las causaajas privativamente por cada litigante o grupo de litigantes; $y$ que, cuando se evidencie que cualquiera de ellos procedió de mala fe, suscitando pretensiones temerarias o dolosas con recursos notoriamente falsos de fundamento o con manifiesto propósito dilatorio, el Tribunal podrá, con independencia de la indemnización de perjuicios, si procediere, imponer, además de las costas, una sanción de carácter pecuniario, acomodada a la importancia cuantitativa del pleito $Y$ a la gravedad del fraude.

El derecho Suizo, tan celoso en la protección de los derechos adquiridos (artículo 646) concede a los accionistas y a la administración el derecho de impugnar ante la justicia las decisiones de la asamblea general que vio. len la ley o los estatutos, así como las decisiones que tengan por objeto crear acciones privilegiadas o las que hayan sido adoptadas en virtud del derecho del voto de que gozan tales acciones cuando originen un perjuicio evidente $\alpha$ los intereses de los accionistas $y$ sin que el fin de la sociedad lo justifique (art. 706).

El Código de Comercio nacional no se refiere en ninguna parte al derecho de impugnación.

Sólo el Código Civil, en el artículo 11 de su Título Preliminar, declara que la ley no ampara el abuso del derecho.

c) Crítica.

Nuevamente en este caso debemos seguir el ejemplo de las legislaciones de Suiza y España en materia tan importante. No basta que la ley declare que no ampara el abuso del derecho. Precisa reconocer expresamente el derecho de impugnación y reglamentarlo para evitar los abusos de la mayoría y también, en ciertos casos, los excesos de la minoría, de las acciones privilegiadas y aún de las acciones comunes. 


\section{Límites de los derechos de los accionistas}

Al tratar sobre los derechos de los accionistas hemos visto las limita-. ciones a que pueden quedar sujetos por voluntad de las partes.

La ley, también, con el fin de hacer guardar ese equilibrio que debeexistir en toda sociedad anónima, en muchos casos pone también sus pro. pias limitaciones.

Así, el derecho de convocar a las juntas requiere en Chile, según el artículo 23 del Reglamento de Sociedades Anónimas, la cuarta parte de las acciones emitidas; en España, artículos 56 y 57, y en Suiza, artículo 699, no menos de la décima parte del capital desembolsado y siempre que indiquen en la solicitud el objeto de la reunión.

El derecho de concurrir a las juntas y de votor en ellas está restringido en Chile a los accionistas que figuren en el registro social y a los tenedores de acciones al portador anotadas en la oficina de la sociedad con diez días de anticipación a la reunión, a lo menos (artículo 24 del reglamento); en España, aun cuando el derecho de concurrir y votar es amplio, se prohibe el voto plural, se suspende el derecho de voto para los accionistas en mora en el pago de los dividendos pasivos y se extingue, salvo disposición expresa de los estatutos en contrario, cuando las acciones hayan sido reembolsadas por la sociedad (artículo 39); $\mathrm{y}$, en Suiza, el artículo 695 priva del derecho de voto a las personas que han cooperado de una manera cualquiera en la gestión de los negocios sociales, cuando se trate de aprobar o desaprobar su respectiva gestión.

El derecho de examinar las cuentas y de solicitar informes, también está condicionado en los diversos países. En Chile, los accionistas no pueden examinar la contabilidad de la administración sino en el término que indica la ley o en la época y forma que lo permitan los estatutos (artículo 462 del Código de Comercio). En España únicamente puede ejercitarse este derecho por medio de censores, de conformidad con lo dispuesto por los artículos 108 y 109. En Suiza, según el artículo 697, los libros son examinados, comúnmente, por los controladores y sólo en virtud de una autorización expresa de la asamblea general o de una decisión de la administración tienen el derecho de inspeccionar los libros y la correspondencia, pero bajo la condición de guardar el secreto de los negocios. Sólo en casos excepcionales puede el Juez obligar a la sociedad a informar a los accionistas suministrándoles extractos certificados de sus libros o de la correspondencia y siempre que se trate de hechos precisos de importancia para el ejercicio del derecho de control. La decisión del juez no debe comprometer los intereses de la sociedad. En el Perú, de acuerdo con los artículos 166 y 180 del Código de Comercio, los accionistas sólo pueden examinar la administración social en la época y en la forma que prescriban los estatutos y reglamentos.

El derecho de percibir dividendos está limitado en Chile por el artículo 466 del Código de Comercio, según el cual se prohibe la repartición de dividendos antes de concretarse el fondo de reserva. En España, de acuerdo con los artículos 106 y 107 de la ley, sólo podrán ser pagados dividendos sobre las acciones en razón de los beneficios realmente obtenidos o de reservas 
expresas de efectivos de libre disposición, siempre que el valor del activo. no sea inferior al capital social; y las sociedades que obtengan en el ejercicio económico beneficios líquidos superiores al $6 \%$ del importe nominal de su capital, deducidos los impuestos, están obligadas a detraer cono mínimo un $10 \%$, hasta constituir un fondo de reserva que alcance la quinta parte del capital desembolsado o mayor, si a ésto les obligan otras disposiciones oficiales. De esta reserva sólo se puede disponer, para cubrir, en su caso, el saldo deudior de la cuenta de pérdidas $y$ ganancias $y$ deberćn reponerlo cuando descienda del indicado nivel. Las cantidades percibidas por la emisión de acciones con prima no podrón ser distribuídas hasta que la reserva legal haya llegado al límite indicado. En Suiza, de acuerdo con los arí́culos 671,674 y 677, la ley exije que se separe anualmente la vigésima parte de las utilidades netas para constituir un fondo de reserva general, hasta que este fondo alcance la quinta parte del capital pagado. También se asigna: al fondo de reserva, aún después de alcanzar el indicado límite:

A) El producto de la emisión de acciones que sobrepase su valor nominal.

B) El saldo que puede por razón de la anulación de acciones y la décima parte del remanente que quede después de separada la cantidad co. rrespondiente $\alpha$ fondo de reserva ordinario y de haberse pagado un dividendo de cinco por ciento a los accionistas y otras personas o entidacies que tengan derecho a participación en los beneficios. En tanto que el fondo de reserva no sobrepase la mitad del capital, no puede se: empleado sino en cubrir las pérdidas o en sostener a la empresa en tiempos de explotación deficitaria.

La ley Suiza también prohibe pagar intereses sobre el capital, deciarando, (artículo 675), que los dividendos sólo pueden ser distribuídos con cargo a las utilidades netas y a las reservas constituídas para este efecto.

El derecho de usar de las preferencias que se hayan otorgado a las acciones privilegiadas, está condicionado, en todas partes, por el principio general de derecho, según el cual tales privilegios no pueden llegar hasta el punto de suprimir totalmente los derechos de los accionistas comunes. La ley Suiza contiene, especialmente, el artículo 646 según el cual los accionistas no pueden ser privados, sin su consentimiento, de los derechos adquiridos que les corresponden como socios.

El derecho de impugnación, así mismo, no es ilimitado, pues sólo se refiere a los casos en que se haya violado los estatutos, o la ley, o los derechos concedidos $\alpha$ los accionistas preferenciales para beneficiar a ciertos accionistas con detrimento de los intereses sociales o del derecho de los demás accionistas.

Se agregan ciertas limitaciones peculiares, como la que existe en Chile, según el artículo 466 del Código de Comercio, que declara nulas las deliberaciones de la Asamblea General, aún adoptadás por unanimidad, cuando versan sobre objetos ajenos a la ejecución del contrato o cuando excedan los límites que prescriben los estatutos.

También son intereeantes las disposiciones del mismo país (artículos 446 y 447 del Código de Comercio y artículo 95 del decreto con fuerza de 
ley $\mathrm{N}^{\circ}$ 251), según las cuales los socios industriales deben dejar sus acciones en depósito hasta que cumplan su empeño; sólo tienen derecho a dividendo $\mathrm{y}$, por consiguiente, no a participar en la distribución del activo so. cial, mientras no haya sido totalmente reembolsado el capital; $\mathrm{y}$, están prohibidos de transferir sus acciones por un plazo de dos años.

En España, el artículo 14 prohibe trasmirir las acciones mientras no esté inscrita la sociedad en el registro mercantil $y$, así mismo, suspende la entrega de los títulos definitivos de acciones, según el artículo 32 , mientras no se haga la revisión de los aportes no dinerarios.

Resalta en este aspecto, como en los demás, la falta de previsión de nuestra ley $y$, por lo mismo, la necesidad indispensable de nuevos preceptos que regulen los derechos, obligaciones y limitaciones a que puedan estar sujetos los accionistas de las sociedades anónimas.

\section{Garantías de la Sociedad Annónima}

Toda sociedad anónima ha de ser organizada en forma tal que proporcione suficiente garantía tanto a sus accionistas cuanto a sus administradores y a los terceros con quienes guarda relación.

Ya hemos explicado cómo las leyes que estudiamos determinan las obligaciones y los derechos de los accionistas considerados individualmente y los límites de tales derechos.

Nos toca referimos ahora a la situación de la sociedad anónima como conjunto, esto es como cuerpo social, y examinar dentro de ellas las seguridades que deben prestar los elementos y organismos que la constituyen tanto dentro de su vida como al momento de su extinción.

Esto nos lleva a estudiar lo siguiente:

A) Las garantías inherentes a los accionistas divididos en grupos, o sea en cuanto tienen intereses diferentes: mayorías y minorías;

B) Las garantías concernientes a la buena administración de la sociedad, como son: la organización y vida de sus asambleas y consejo de administración y la continuidad de tales organismos;

C) Las garantías relativas a su vida económica;

D) Limitación de actividades;

E) Las garantías que deben proporcionarse al momento de su extinción o liquidación;

F) Las garantías que deben proporcionarse a los acreedores.

A) Maryorías y Minorías.

a) Mayorías.

Siendo la sociedad anónima una organización de tipo democrático, debe en esencia ser gobernada por la voluntad de la mayoría de sus miembros.

Este principio básico se halla asegurado tanto en España (arts. 48, 58 y 71) como en Suiza (art. 703) y en el Perú (art. 159), pues las tres legislaciones expresan que las decisiones de las juntas de accionistas se tomarán por mayoría de votos.

Sin embargo, esta declaración no basta pues para hablar de "mayoría"; 
debe saberse primero en qué consiste; esto es si para computarla debe tomarse en cuenta a todos los accionistas de la sociedad o solamente a los que concurran a la respectiva junta; y qué cantidad o proporción de votos se requiere para formarla.

Como ello incide también en el problema de la protección de las mino. rías, lo trataremos a continuación.

b) Minorías.

Las minorías deben respetar, sin duda, las decisiones de las mayorías, pero también debe evitarse que éstas abusen y de allí que las legislaciones examinadas establezcan una serie de taxativas que limitan el derecho de las mayorías, reduciendo así el riesgo que corren los demás accionistas.

Estas limitaciones consisten:

(1) En permitir a las minorías que convoquen a juntas de accionistas como sucede en Chile (art. 23 del Reglamento), en España (arts. 56 y 57), y en Suiza (art. 699).

(2) En exigir determinado quorum mínimo para cierta clase de juntas (en España artículos 51 y 58; en Suiza, artículo 649; y en el Perú, artículo 175).

Contrasta la legislación peruana con la española y la suiza en que la peruana exige imperativamente la concurrencia de dos tercios del número de accionistas y la representación de dos tercios del capital para los casos de cumento o reducción del capital, reforma de estatutos o disolución de la sociedad, cualquiera que sea el número de convocatorias que se haga para la junta (art. 175 que examinaremos luego con más detalle), permitiendo así que una minoría ligeramente superior $\alpha$ un tercio de los accionistas frustre la reunión, mientras que la legislación española más lógicamente, en el artículo 58, permite en tales casos reunir la junta en una segunda convocatoria con la mayoría de los accionistas que representen la mitad del capital desembolsado o sólo esta última representación cuando las acciones sean al portador.

En Suiza, se requiere dos tercios para la primera convocatoria, pero en la segunda basta la concurrencia de un tercio de los accionistas.

(3) En exigir determinado número de votos para adoptar ciertas decisiones o en señalar cierta forma para la votación a fin de asegurar los derechos de las minorías.

Ásí, en Chile, el artículo 97 del Decreto con fuerza de ley $\mathrm{N}^{\circ} 251$, exige que todas las elecciones que se efectúen en las asambleas de accionistas se hagan por voto unipersonal; en España, según el artículo 71, la elección de miembros del Consejo de Administración se hace por medio de votaciones en las cuales las acciones que voluntariamente se agrupen hasta constituir una cifra del capital social igual a la que resulta de dividir por el número de miembros del Consejo de Administración, tendrán derecho a nombrar los que correspondan $\alpha$ la parte del capital que llegue $\alpha$ formar el grupo.

En Suiza, el artículo 648 dispone que las decisiones que tengan por objeto la transformación del fin social o la supresión de cláusulas estatutarias que agraven las condiciones bajo las cuales puede adoptar decisiones la 
asamblea general, o la introducción de acciones con derecho a voto privilegiado, deben ser aprobadas por votos de, por lo menos, dos tercios del conjunto del capital social.

Agrega el mismo artículo quie los propietarios de acciones nominativas que no se han adherido a la decisión no quedan sometidos a las restricciones que puedan haber sido introducidas por los estatutos al derecho de enajenar las acciones dentro de un plazo de seis meses desde la publicación de la decisión en la Hoja Oficial Suiza de Comercio.

En el artículo 649, la misma ley suiza prescribe que, salvo disposición contraria de los estatutos, las decisiones por los cuales la sociedad extiende el círculo de sus operaciones comprendiendo negocios anólogos cuando que. dan dentro de los límites del fin social, o que restrinjan este círculo, no pueden ser adoptadas sino en una asamblea general en que estén representados por lo menos dos tercios de todas las acciones; y ocurre lo mismo para las decisiones que tienen por objeto una fusión y para aquellas que prolongan la duración de la sociedad mós allá del tiempo previsto en los estatutos o que modifican su razón social o que transfieren su sede o que provocan su disolución antes del término fijado por los estatutos. Cuando una primera asamblea general no reúne dos tercios de todas las acciones, puede convocarse una segunda asamblea, en la cual pueden adoptarse las decisiones previstas anteriormente si solo un tercio de todas las acciones está representado.

Agrega que, salvo disposición contraria de los estatutos, la segunda asamblea no puede tener lugar sino, por lo menos, ocho días después de la primera.

En los otros países, inclusive en ei Perú, basta el quorum que exige la ley para que se decida por mayoría.

(4) En hacer respetar los derechos de los accionistas, sea de los ordinarios cuando van a crearse acciones preferenciales o de las acciones preferenciales cuando se desea modificar sus prerrogativas.

Para este efecto el artículo 38 de la ley española dispone que para la creación de acciones que confieran algún privilegio trente a las ordinarias habrá de observarse las formalidades prescritas para la modificación de estatutos; y los artículos 654 y 655 del Código Suizo declaran que si hay acciones preferentes no puede emitirse nuevas acciones con ventajas mayores sin la aprobación de una asamblea especial de los accionistas afectados y de una asamblea general de todos los accionistas, requiriéndose para esta última asamblea la presencia de dos tercios de todas las acciones.

En el Perú, la legislación no dice nada al respecto.

(5) En conceder a todos los accionistas el derecho de impugnación que ya hemos examinado anteriormente.

B) Garantías de la buena administración.

a) Asambleas.

En Chile, el artículo 466 del Código de Comercio y los artículos 20 a 30 de su Reglamento, determinan con toda precisión, qué clases de juntas habrá, cómo se les citará, quién gozará del derecho de convocarlas, cómo 
serán registrados los accionistas con derecho a concurrir, la facultad que tendrán de hacerse representar por apoderado, cómo ejercitarón su derecho de votar, el quorum requerido para que se instale la junta, cómo se adoptarán los acuerdos, quién presidirá, cómo se llenarón las actas y quién las firmará.

En España, sucede lo mismo en los artículos 43 al 70 distinguiéndose por su mayor minuciosidad por declarar expresamente que todos los accionistas, inclusive los disidentes, y los que no hayan participado en la reunión de las juntas quedan scmetidos a sus acuerdos (crículo 48); y por permitir que las actas sean aprobadas por las juntas o, dentro de un plazo de quince días por el Presidente $y$ dos interventores, uno en representación de la mayoría y otro de la minoría.

Es también notable en la legislación española la forma como reglamenta el derecho de los accionistas a impugnar los acuerdos que sean contrarios a la ley, se opongan a los estatutos o lesionen en beneficio de uno o varios accionistas, los intereses de la sociedad (artículos 67 al 70 ya citados).

En Suiza, el Código (artículo es: deciara cue la ascmblea general de accionistas es el poder supremo de la sociedad y que tiene el derecho inalienable de adoptar y modificar los estatutos; de nombrar los administradores, de aprobar las cuentas, memoria de la gestión, empleo de beneficios y distribución de utilidades; de despedir a los administradores y de adoptar las decisiones que le reserve la ley.

En los artículos 699 al 700 , do:cilla tcmbién nouy cuidadoscmente todo lo relativo a las asambleas, permitiendo convocarlas no sólo a los administradores, sino también a los controladores, a los liquidadores, a los representantes de tenedores de bonos u obligaciones de la sociedad y a grupos de accionistas que posean no menos de un décimo del capital social. Señala también las épocas de la reunión de las juntas ordinarias, formas de convocarlas, medidas preparatorias, modo de adoptar acuerdos $\mathrm{y}$ de registrarlos y declara expresamente el derecino de la administración y de cualquier accionista a impugnar ante la justicia las decisiones de la asamblea que violen la ley o los estatutos o cuando originen perjuicio evidente a los derechos de ciertos accionistas preferidos o comunes sin que el fin de la sociedad lo exija.

En el Perú, el artículo 159 del Código de Comercio manda que en los estatutos se haga constar las plazos y forma de convocación y celebración de las juntas generales ordinarias de socios y los casos y el modo de convocar las extraordinarias. También obliga a someterse en los mismos estatutos al voto de la mayoría y a indicar el modo como se contará y constituirá la mayoría.

En el artículo 175 ya citado, reglamenta la forma de acordar la reducción o aumento de capital, la reforma de estatutos y la disolución de la sociedad, exigiendo un quorum no menor de los dos tercios del número de accionistars y del capital de la sociedad y mandando que en la convocatoria para juntas de esta naturaleza se haga constar expresamente el objeto de la reunión.

De esta comparación salta a la vista que si bien la legislaclón chile- 
na es satisfactoria en esta materia, las legislaciones de Suiza y España son más perfectas. La nuestra en cambio evidencia la falta absoluta de reglamentación abandonando a los estatutos el establecer todas las garantías $\mathrm{y}$ derechos pertinentes.

De la carencia de legislación expresa, de la mala redacción de los estatutos en algunos casos, y en otros de su redacción negligente o dolosa, surgen, naturalmente, toda clase de abusos y litigios, los que se hacen más odiosos por no existir entre nosotros el derecho de impugnar los acuerdos y mandar disponer la ley, por lo contrario, que los accionistas se sujeten al mandato de la mayoría.

El artículo 175 que contiene un intento de control no llega a ser efectivo $\mathrm{y}$ más bien produce el efecto contrario, pues, de un lado al exigir siempre un quorum de dos tercios del capital y dos tercios de los accionistas para las decisiones más importantes, permite $\alpha$ una minoría ligeramente mayor de un tercio bloquear la vida de la sociedad, si se abstiene de concurrir y también faculta a un grupo numeroso de accionistas, aunque no sea más de la mitad, para oprimir a los demós, pues basta que exista ese quorum de dos tercios para que se tome toda clase de decisiones por mayoría de votos o sea, que si hubiere el quorum de dos tercios, un poco más de la tercera parte de los accionistas podría obligar a todos los socios sin derecho de impugnación por parte de éstos; salvo que se reunieran en mayoría en nueva junta para revocar el acuerdo, cunque esto último podría evitarlo la minoría (mayor de un tercio) que logró dominar en una junta absteniéndose de concurrir a las futuras juntas a fin de evitar que tengan el quorum de dos tercios.

Así mismo la ley peruana al exigir el quorum de dos tercios de los accionistas no tiene en cuenta que cuando existen acciones al portador no hay forma de computar el número de cccionisias que tiene la sociedad, salvo el caso de que todos registren sus acciones para concurrir a la junta.

Por todo esto, nos inclinamos a la adopción de los principios de las legislaciones de Suiza y España, opinando que para evitar largos juicios en los casos de impugnación de los acuerdos de las juntas y los consiguientes perjuicios a la sociedad o a los impugnadores, el procedimiento de impugnación debería ventilarse en la vía arbitral, sea en la forma que para tal efecto convengan las partes o ante una Cámara de Comercio del país.

\section{b) Administradores.}

Para el buen ejercicio de sus funciones los aáministradores deben gozar de determinados derechos $y$ tener ciertas obligaciones y responsabilidades ineludibles.

En Chile el artículo 457 del Código dice que la sociedad anónima es administrada por mandatarios temporales $\mathrm{y}$ revocables, sean 0 no socios, sean asalariados o gratuitos, elegidos en la forma que prevengan los estatutos de la sociedad. Prohibe que se pacte la irrevocabilidad del mandato aunque sea una condición del contrato social.

El artículo 97 del decreto que con fuerza de ley $\mathrm{N}^{\circ} 251$ y el artículo 14 del Reglamento disponen que sean nómbrados en las asambleas de accio- 
nistas, por voto unipersonal, esto es votando cada accionista por una solor persona y resultando elegidas las que en una misma y única votación hayan obtenido el mayor número de votos, hasta completar el número de personas por elegir.

Permite sin embargo adoptar otro sistema por acuerdo unánime de los asistentes o cuando existan diversas clases de acciones.

Sin perjuicio de lo expuesto en los artículos 461 y 467 del Código, en los artícuios 97 al 102 del Decreio con fuerza de ley $N^{\circ} 251$ y en los artículos 10 al 19 del reglamento; la legislación chilena indica cómo funcionará el Directorio si los estatutos no han dispuesto nada sobre la materia; de las reglas para la duración de su mandato, revocación del cargo, modo de llenar las vacantes, quorum, presidencia, modo de adoptar los acuerdos y de llevar las actas, obligación de presentar memorias y balances, etc. etc.

En especial debemos llamar la atención sobre el artículo 458 del Có. digo que dice que los administradores no son responsables sino de la ejecución del mandato que recibieren y que es nulo todo pacto que tienda a absolverlos de esta responsabilidad o a limitarla; el artículo 10 del Decreto con fuerza de ley $\mathrm{N}^{\circ} 251$ que les impide intervenir en debates de asuntos en que tengan interés personal; el artículo 19 del Reglamento que les permite salvar su responsabilidad haciendo constar en acta las decisiones que desaprueben $\alpha$ fin de que se de cuenta en la junta ordinaria de accionistas más próxima; el artículo 17 del Reglamento que permite aplicar una multa hasta de $\$ 5,000.00$ al Director que no constituye la garantía exigida por los es tatutos durante el mes siguiente a la fecha en que acepte el cargo o a ia fecha del decreto que autorice la existencia de la sociedad, cuando se les nombre en la escritura de fundación; el artículo 102 del Decreto con fuerza de ley $N^{\circ} 251$ que impide la delegación del mandato; el artículo 101 del mismo decreto que hace perder el cargo de hecho en caso de ausentarse el Director por más de tres meses; y el artículo 114 del decreto 251 antes citado en que se manda publicar todo cambio del directorio en un diario del domicilio social y comunicarlo a la Superintendencia.

En España, el artículo 71 de la ley también confía a la junta de accionistas el nombramiento de los administradores y la determinación de su número cuando los estatutos establezcan solamente el máximo y el mínimo y declara que en defecto de disposición estatutaria serán las juntas las que fijen las garantías que deberán otorgar los administradores o relevarlos de esta prestación.

No exige tampoco la calidad de accionista para ser director; y para: las elecciones permite a los socios unir sus acciones para elegir un di rector (pero no más) por su respectivo grupo, si llegan a tener en tal forma la cantidad de votos necesarios para ello.

Fija el plazo de duración del cargo en no más de cinco años renovables, para los designados en el acto de fundación $y$ ordena que en cualquier caso el nombramiento se inscriba en el Registro Mercantil (artículo 72).

De los artículos 71 y 73 se desprende que la administración puede ser confiada $\alpha$ una sola persona o a un Directorio o Consejo de Administración compuesto de varias personas que pueden o no ser accionistas. 
La ley española es más flexible que la chilena al permitir mayores facilidades para que en los estatutos o por decisión de la junta de accionistas se regule el funcionamiento de la administración, pero también detalla las reglas concernientes al quorum, adopción de acuerdos, separación, incompatibilidad y responsabilidades (arts. 71 al 83).

De un modo especial, en el arículo 79, dispone que: "Los administra"dores desempeñarán su cargo con la diligencia de un ordenado comercian"te $\mathrm{y}$ de un representante legal, $\mathrm{y}$ responderón frente a la sociedad, frente "a los accionistas y frente a los acreedores del daño causado por malicia, "abuso de facultades o negligencia grave. En cualquier caso estarán exen"tos de responsabilidad los administradores que hayon salvado su voto en "los acuerdos que hubieren causado daño".

Permite, de otro lado, al Consejo de Administración regular su funcionamiento y la formación de una comisión ejecutiva o la designación de uno o más consejeros delegados del Directorio, prohibiendo solamente de. legarles la obligación de rendir cuentas y de presentar balances, y las facultades que la junta general otorgue al Consejo (art. 77).

Manda fijar en los estatutos (art. 74) la retribución del Consejo y dispone que cuando consiste en una participación "en las ganancias, sólo podró "ser detraída de los beneficios líquidos y después de estar cubiertas las "atenciones de la reserva legal y de la estatutaria y de haberse reconocido "a los accionistas un dividendo del cuatro por ciento o el tipo más alto que "los estatutos hayon establecido".

En el artículo 80 reglamenta cuidadosamente el ejercicio de la acción de responsabilidad contra los administradores y en el artículo 81 establece que ésto es sin perjuicio de las acciones de indemnización que pudieran corresponder a los socios y a terceros por los actos de los administradores que lesionen directamente los intereses de aquellos.

El artículo 83, finalmente, dispone que los administradores que estuvieren incursos en cualquiera de las prohibiciones que establece la ley para ser tales deberán ser inmediatamente destituídos a petición de cualquier accionista sin perjuicio de la responsabilidad en que puedan incurrir por su conducta desleal.

Agrega "que los administradores que lo fueren de otra sociedad com"petidora y las personas que bajo cualquier forma tengan intereses opuestos "a los de la sociedad cesarón en su cargo a petición de cualquier socio y "por el acuerdo de la Junta general".

Como se vé, mientras que en Chile se cuida de reglamentar en detalle el funcionamiento interno del Directorio, en España las reglas son más genéricas a este respecto, pero en cambio se define con mucha precisión las responsabilidades de los administradores y el modo de hacerlas efectivas.

En Suiza, el Código de las Obligociones tarnbién dispone (art. 708) que los aministradores serón elegidos por la Asamblea General, la primera vez por un plazo que no excederó de tres años y a continuación, a lo mós, por seis años, salvo disposición en contrario de los estatutos, permitiéndose la reelección.

Los administradores deben ser accionistas (art. 707) y depositar accio- 
nes durante el ejercicio para asegurar el cumplimiento de sus funciones (art. 709). La elección puede recaer en una o más personas (art. 707), pero el artículo 708 dispone que si hay varios grupos de accionistas cuya situación jurídica es diferente, los estatutos deben asegurar a cada uno de ellos la elección de, por lo menos, un representante en la administración.

Agrega que los grupos importantes tienen derecho a ser representados también en los Comités que se constituyen en el seno del Consejo de Administración; y que, con el fin de proteger a las minorías o a ciertos grupos de accionistas, los estatutos pueden regular diferentemente el modo de elección.

Como en España, la legislación suiza determina qué cuando dos o más personas están encargadas de la administración, forman Consejo de Administración, y que sus poderes, salvo disposición expresa de la ley, se definirán en los estatutos o en un reglamento previsto por los estatutos, pudiendo inclusive encargarse al Consejo de Administración de hacer su propio reglamento (art. 712).

La ley suiza se caracteriza por conferir expresamente a los administradores determinados derechos inalienables $y$ por señalarles, igualmente, ciertas obligaciones imperativas.

Entre los derechos podemos mencionar el derecho de pedir que comparezcan las personas encargadas de dirigir y representar a la sociedad (art. 713); de pedir informes sobre la marcha de la empresa y sobre negocios determinados $y$ de ordenar que se exhiban los libros $y$ archivos. También pueden pedir que se convoque a reunión del Consejo.

Si bien los estatutos o reglamento señalan los poderes de los administradores, el artículo 718 dispone que las personas autorizadas para representar a la sociedad tienen el derecho de practicar en nombre de ella todos los actos que puedan implicar el fin social sin que tenga efecto res. pecto de terceros de buena fe la limitación de estos poderes.

Entre las obligaciones debe mencionarse especialmente la de preparar las deliberaciones de la Asamblea y de ejecutar sus decisiones; la de aprobar los reglamentos indispensables para la marcha del negocio $\mathrm{y}$ dar las instrucciones necesarias para su dirección y la de vigilar a las personas encargadas de la gestión y de la representación para asegurar a la empresa una actividad que esté de acuerdo con la ley, los estatutos y los reglamentos.

También es responsable de que se lleve en orden las actas; los libros de contabilidad y las cuentas en general, y de su examen por los contraladores (art. 722).

En las sociedades cuyo capital se eleva a cinco millones de francos o más, o que adeudan obligaciones por empréstitos, o que anuncien públicamente que acepta̛n dinero de terceros, la administración debe hacer examinar el balance por expertos contadores, por sociedades fiduciarias o por sindicatos de revisión. Debe presentar a la Asamblea General un informe de su gestión (art. 724), y deben dar aviso oportuno a la Ascrmblea de la reducción del capital que pueda conducir a insolvencia de la sociedad (art. 725). 
La ley también permite (art. 714) que en el seno del Consejo de Ad. ministración se forme uno o más Comités con el objeto de controlar la marcha de la empresa, preparar las materias de deliberación, informar sobre todas las cuestiones de cierta importancia $y$ en particular, velar por la confección del balance y la ejecución de las decisiones.

Desde luego, la ley reglamenta la forma de designar al Presidente y al Secretario (art. 714), el modo de llevar las actas (art. 715) y de tomar decisiones, permitiendo inclusive que éstas sean adoptadas mediante una aprobación escrita, sin necesidad de reunir a los miembros del Consejo, siempre que se hagan constar por acta (art. 716).

La ley igualmente declara la responsabilidad de la sociedad (art. 718) por los actos ilícitos de sus gestores y para asegurar la publicidad de los nombramientos dispone (art. 720) que la Administración está obligada a comunicar al encargado del Registro de Comercio, los nombres de las personas que tienen derecho de representar a la sociedad, a fin de que se haga la inscripción respectiva.

En el Perú, el artículo 159 del Código dispone que en la escritura social se designará la persona o personas que deberán ejercer la administración y el modo de proveer las vacantes, disposición que se confirma en el artículo 163 y que se amplía en el artículo 164 expresando que los administradores de las compañías anónimas son sus mandatarios; y, que mientras observen las reglas del mandato, no estarán sujetos a responsabilidad personal ni solidaria, por las operaciones sociales; y si, por la infracción de las leyes y estatutos de la companía, o por la contravención a los acuerdos legítimos de sus juntas generales, irrogaren perjuicios $y$ fueren varios los responsables, cada uno de ellos responderá a prorrata.

De todas estas disposiciones se desprende que en los países cuyas legislaciones examinamos, los administradores principales de una compañía anónima son designados por los accionistas; que, por lo general, son los estatutos los que reglamentan el funcionamiento de los directorios o consejos de administración y los poderes de los manatarios; que los aministradores pueden ser uno o más y que sólo en Suiza se exige que sean accionistas, y que en Chile, España y Suiza la ley señala obligaciones y derechos mínimos de los directores $y$, en todo caso, contiene disposiciones supletorias para el caso de deficiencia de los estatutos; y que nuestra legislación se distingue por la falta de reglamentación, pues no contiene prácticamente ninguno de los principios a que hacemos referencia, todos saludables y dignos de ser adoptados, salvo el que obliga a que los administradores sean accionistas, pues en la próctica se convierte en una ficción, ya que quien desea poner como administrador a uno que no sea accionista puede prestarle sus acciones para llenar el requisito formal, lo que, evidentemente, no llena el objetivo principal de la ley.

c) Continuidad en la administración.

Algunas de las legislaciones examinadas se preocupan no sólo de las obligaciones, derechos y responsabilidades de los administradores, sino 
también de impedir que la sociedad pueda quedar sin gobierno por cesación de uno o más de sus administradores.

Para ello en Chile, el artículo 98 del Decreto con fuerza de ley $N^{\circ} 251$, dispone que si por cualquiera causa no se celebrare, en la época establecida, la asamblea de accionistas llamada a hacer la elección periódica de los directores, se entenderán prorragadas las funciones de los que hubieren complido su período hasta que se les nombre reemplazantes, $y$ el Directorio estará obligado a provacar, a la brevedad posible, una asamblea para hacer el nombramiento.

En Suiza, el artículo 708 del Código de las Obligaciones declara que si uno o más miembros de la administración cesan en sus funciones en el curso de un ejercicio, o estón impedidos para ejercerlas, los otros miembros pueden, salvo disposición en contrario de los estatutos, continuar la gestión hasta la próxima asamblea general.

Evidentemente en el Perú faltan disposiciones de esta clase. Normalmente, si vence el plazo para el cual fué elegido un Directorio y las estatutos no proveen nada sobre la materia, la sociedad puede quedar acéfala.

\section{C) Garantías relativas a la vida económica de las sociedades.}

En todos los países de que nos ocupamas la ley establece determinadas garantías de carácter económico que esencialmente se refieren $\alpha$ su control permanente, $\alpha$ la memoria y balance, $\alpha$ los dividendos, $\alpha$ las reservas y a la exacta prosecución de sus fines.

a) Control económico permonente.

El control económico de las sociedades anónimas se realiza en Chile mediante la Superintendencia de Sociedades Anónimas (art. 83 del decreto con fuerza de ley $N^{\circ}$ 251).

En España se pueden designar censores de cuentas $y$ comisiones extraordinarias de investigación (arts. 108 y 109).

En Suiza existe todo un capítulo (arts. $727 \propto$ 731) que faculta $\alpha$ la Asamblea General para elegir uno o más controladores y reglamenta las actividades de éstos, exigiendo, en determinadas ocasiones, que las cuentas sean examinadas por expertos contadores (crt. 723).

El Perú se limita a adherirse a Ia regla general según la cual los accionistas pueden examinar las memorias y cuentas en la época correspondiente a la presentación de balances (art. 166).

b) Memoria y balance.

En Chile el crtículo 461 del Código dispone que los administradores presentarón a la asamblea general, en las épocas en que se reuna, una memoria razonada acerca de la situación de la sociedad, acompañada de un balance de haberes $\mathrm{y}$ deudas $\mathrm{y}$ de un inventario detallado $\mathrm{y}$ preciso de las existencias, $y$ que remitirán una copia de ella a la Superintendencia respectiva y otra al juzgado de comercio del domicilio social; que las socieda- 
des que emitan acciones al portador publicarán estas piezas en uno de los periódicos del enunciado domicilio; y que el balance, inventario, actas, libros y demás piezas justificativas de la memoria serón depositados en la oficina de la administración ocho días antes del señalado para la reunión de la asamblea general, encargando a la Superintendencia de Sociedades Anónimas fijar las normas generales para confección de los balances y comprobación de su exactitud. La misma Superintendencia vela por la comunicación de estos documentos (art. 83, inciso h) del Decreto $N^{\circ} 251$ y artículo 31 del Reglamento).

En España, los artículos 102 a 110 reglamentan con gran detalle la obligación de presentar el balance, con la cuenta de ganancias y pérdidas, la propuesta de distribución de beneficios y la memoria explicativa, diciendo expresamente que la contabilidad cerrada en cada ejercicio reflejará con claridad y exactitud la situación patrimonial de la sociedad y los beneficios obtenidos durante el ejercicio o las pérdidas sufridas; $y$ que el balance, la cuenta de pérdidas y ganancias y la memoria se redactarán de modo que con su lectura pueda obtenerse una representación exacta de la situación económica de la compañía y del curso de sus negocios (art. 102).

Son dignos de éspecial mención los artículos 103, 104 y 105, en los que se especifica las partidas que cada balance debe contener en el activo y pasivo, la forma cómo deben avaluarse los bienes y el modo de formar la cuenta de pérdidas y ganancias.

En Suiza, los artículos 661 a 670 reglamentan igualmente el modo de hacer el balanice, cuidando de señalar el valor que se atribuirá a los bienes, cómo se castigarán los gastos de fundación, cómo se avaluará lass instalaciones permanentes, las mercaderías, los valores, los capitales, etc., cómo se dará cuenta de las obligaciones de la sociedad y de sus respectivos compromisos, etc. etc.

También obliga (art. 724) a presentar anualmente un informe de las actividades de la administración.

El Perú, en el artículo 165 dispone que las compañías anónimas ten. drán obligación de publicar anualmente en un periódico diario, el balance detallado de sus operaciones, expresando el tipo a que calculen sus existencias en valores y toda clase de efectos cotizables; pero, no reglamenta en lo absoluto la materia.

Sin duda si se siguiera el ejemplo de las legislaciones de España o de Suiza, el examen de las cuentas de las sociedades sería más accesible a los accionistas, pues en la actualidad dista mucho de serlo.

\section{e) Dividendos.}

En Chile, el Código de Comercio, en el artículo 463 cuida de decir que los dividendos se descontarán exclusivamente de los beneficios líquidos justificados por los inventarios y balance, aprobados por la Asamblea General de Accionistas.

La ley española contiene disposición análoga (art. 107) determinan- 
do que sólo podrán ser pagados dividendos sobre las acciones en razón de beneficios realmente obtenidos o de reservas expresas de efectivos de libre disposición, siempre que el valor del activo no sea inferior al capital social.

En Suiza, existen disposiciones semejantes (art. 674 a 678) distinguiéndose la legislación de ese país por su mayor detalle, y porque si bien prohibe (art. 675) pagar intereses sobre el capital social, permite determinadas excepciones (art. 676) en favor de los accionistas por el período de los trabajos de preparación de la empresa o por emisión de nuevas acciones que pueden ganar interés, mientras se hacen nuevas instalaciones.

El artículo 678 declara expresamente que el accionista que ha percibido indebidamente $\mathrm{y}$ de mala fe, dividendos o intereses, está obligado $\alpha$ restituirlos, y que en caso de quiebra (art. 679), los administradores están obligados a restituir a los acreedores sociales las sumas que hayan percibido como partes de beneficio o bajo otra denominación en el curso de los tres últimos años que precedió a la declaración de quiebra, en tanto que. aquellas sumas excedan de lo que hubiera tocado a los administradores como indemnización apropiada de sus fuciones; $y$ en vista de un balance debidamente confirmado.

La falta de dispasición al respecto en la legislación peruana no requiere comentario.

\section{d) Reservas.}

En Chile, el artículo 463 del Código prohibe la repartición de dividen. dos contes de completar el fondo de reserva y en los artículos 105 y 106 del decreto con fuerza de ley $\mathrm{N}^{\circ}$ 251, indica que el fondo de reserva lega está constituído por una cuota no inferior al $5 \%$ de las utilidades de cada ejercicio, hasta formar un fondo que represente al menos el $20 \%$ del capital social.

Al mismo tiempo dispone que la cantidad que se separe para reservas especiales no podrá ser superior al $30 \%$ de las utilidades, debiendo distribuirse el resto como dividendo, salvo que la escritura social establezca otra cosa.

En España, el artculo 106 dispone que las sociedades que obtengan en el ejercicio económico beneficios líquidos superiores al $6 \%$ del importe nominal de su capital, deducidos los impuestos, vendrán obligadas a detraer como minimo un $10 \%$, hasta constituir un fondo de reserva que alcance la quinta parte del capital desembolsado, o mayor, si a ésto les obliga otras disposiciones oficiales. De esta reserva sólo podrán disponer para cubrir, en su caso, el saldo deudor de la cuenta de pérdidas y ganancias, y deberán reponerlo cuando descienda del indicado nivel.

En Suiza, la legislación de esta matieria es la más detallada. Está coptenida en los artículos 671, 672,673 y 674.

Según tales artículos, igualmente debe separarse una vigésima parte del beneficio neto para constituir un fondo de reserva general hasta que este fóndo alcance una quinta parte del capital social ya pagado (art. 671).

Agrega el mismo artículo que debe acumularse al fondo de reserva. además, lo siguiente: 
a) El producto de la emisión de acciones que sobrepase el valor nominal, después de pagar los gastos de emisión, en cuanto no se haya empleado en amortizaciones o en fines de beneficencia.

b) El saldo de los desembolsos hechos sobre acciones anuladas, de. ducción hecha de la pérdida sufrida sobre las acciones emitidas en su lugar y sitio.

c) El décimo de los montos que se reparten por cargos sobre el beneficio neto, después de los desembolsos ordinarios en los fondos de reserva y en el pago de un dividendo de cinco por ciento a los accionistas y otros: derecho-habientes.

También agrega que en cuanto el fondo de reserva no sobrepase la mitad del capital social no puede ser empleado sino en cubrir las pérdidas o en tomar medidas que permitan a la empresa mantenerse en tiempo de explotaciones deficitarias, evitar la desocupación o atenuar sus consecuencias.

Desde luego, el artículo 672 permite que el fondo de reserva sea superior al $20 \%$ del beneficio neto y que llegue a mós del quinto del copital social desembolsado; el artículo 673 permite afectar las utilidades para fines de beneficencias; y por último, en el artículo 674, al autorizar la constitución de reservas adicionales, permite acumular reservas en la medida necesaria para asegurar en forma duradera la prosperidad de la empresa o la repartición de un dividendo tan constante como sea posible.

Nuestro Código no legisla sobre Ia materia.

Una vez más parece innecesario decir que conviene legislar al respecto estableciendo la obligación de constiuuir reservas mínimas, pero también evitando que bajo el manto de la constitución de reservas se deje de repartir dividendos, para obligar a las minorías a vender sus acciones.

D) Limitación de actividades.

a) Cambio de tines.

Garantía de particular interés es aquella que impide a las sociedades cambiar el fin social o ampliar sus actividades sin consentimiento de todos los interesados.

En Chile se llega a declarar nulas las deliberaciones de Ia asamblea. aunque se hayan adoptado por unanimidad, cuando versan sobre objetos ajenos a la ejecución del contrato social o cuando excedan de los límites que prescriben los estatutos.

En España, el artículo 85 permite a los accionistas que no hayan votado en favor del acuerdo, separarse de la sociedad; y en Suiza (art. 648) las decisiones que tengan por objeto el cambio del giro social deben ser aprobadas por los votos de dos tercios del capital.

En el Perú, según el artículo 175, para reformar estatutos se requiere la presencia de una mayoría igual, por lo menos, a los dos tercios del ca. pital y a los dos tercios del número de accionistas.

Consideramos que sobre esta materia la legislación española podrít servir de base, pues a nadie puede obligórsele a permanecer en una sociedad que se va a dedicar $\alpha$ fines completamente distintos de aquellos para los cuales el interesado aportó su dinero. 


\section{b) Adquisición de sus propias acciones.}

Otra limitación a las actividades de las sociedades es la de no poder adquirir sus propias acciones o prestar dinero sobre ellas.

En Chile (art. 103 del Decreto N' 251), sólo se puede adquirir las accianes de la sociedad previo visto bueno de la Superintendencia con utilidades líquidas o fondos especiales.

En España el artículo 47 de la ley dispone que:

(1) La sociedad podrá adquirir sus propias acciones con cargo al capital social únicamente para amortizarlas, previo acuerdo de reducción de capital, adoptado conforme a las disposiciones de la ley.

(2) Con los beneficios y reservas libres, y al solo efecto de amortizarlas, podrá la sociedad adquirir sus acciones por compra-venta o permuta. Con cargo a esos mismos bienes, y por otro título oneroso, podrá también la sociedad adquirir las acciones sin necesidad de amortizarlas, cuando la adquisición se haga para evitar un daño grave y haya sido autorizada por acuerdo de la junta. Es lícita la adquisición de acciones propias a título gratuito.

(3) Las acciones que adquiera la sociedad a título oneroso deberán estar totalmente desembolsadas, y en los supuestos en que no haya de amortizarlas, deberá venderlas en el más breve plazo. Entre tanto quedará en suspensión el ejercicio de los derechos incorporados a las acciones que posea la sociedad.

En Suiza, el artículo 659 contiene una disposición semejante, pues prohibe a la sociedad readquirir sus acciones o recibirlas en prenda, salvo en los siguientes casos:

I. Cuando las acciones son adquiridas en ejecución de un acuerdo que signifique la reducción del capital social;

II. Cuando son adquiridas en pago de créditos de la sociedad; a menos que éstos no resulten de la suscripción de acciones;

III. Cuando la adquisición tiene lugar como consecuencia de la asunción de un patrimonio o de una empresa con activo y pasivo;

IV. Cuando la adquisición o la prenda se vincula a operaciones que los estatutos comprenden entre las de la sociedad; y

V. Cuando administradores, directores o empleados de la sociedad depositen acciones en garantía del ejercicio de sus funciones.

En el caso previsto bajo el primer inciso, las acciones adquiridas por la sociedad deben ser canceladas inmediatamente. En los otros casos serán enajenadas tan pronto como lo permitan las circunstancias.

Las acciones adquiridas o enajenadas por la sociedad deben mencionarse en la memoria del ejercicio $y$ no pueden ser representadas en la asamblea general.

Fn el Perú, los artículos 173 y 174 establecen de un modo general la prohibición, permitiendo la adquisición de las acciones de la sociedad sólo con los beneficios del capital social, para el efecto de amortizarlas, $y$ salta 
a la vista que hacen falta disposiciones análogas a las de España y Suiza, pues es evidente que una sociedad puede adquirir sus propias acciones $\alpha$ título gratuito si se trata de evitar daños graves, o en pago de créditos de la sociedad, por absorción de otra entidad, o como consecuencia de la ejecución de responsabilidades de terceros o de los aministradores o miembros de la sociedad.

E) Garantías en la liquidación de la Sociedad.

Muy importante es para los accionistas la forma cómo se reglamenta la liquidación de la sociedad y por eso todas las legislaciones comentadas atienden el punto.

Ia Chilena en los artículos 465 y 466 del Código de Comercio y 40 a 46 del Reglamento detallan cómo se producirá la liquidación y las facultades y obligaciones de los liquidadores.

En España, sucede algo semejante en los artículos 133 al 171 que in. clusive reglamentan los casos de transformación o fusión. y 751.

En Suiza, la materia está cubierta extensamente por los artículos 736

La legislación peruana no deja de legislar sobre el punto (arts. 211 y 231), pero mezclando disposiciones sobre sociedades anónimas con las de otra clase de sociedades y señalando preferentemente las causas de liquidación y algunas obligaciones y responsabilidades de los liquidadores.

Por su mayor reglamentación y por prever los casos de transformación y fusión de sociedades, la legislación de España es la más recomendable.

\section{F) Garantías para los acreedores.}

A los acreedores se les garantiza en todos los países a que nos rerefirimos mediante la reglamentación de las memorias y balances, con medidas apropiadas que ya hemos señalado para reducción del capital y determinando la forma de liquidar las empresas.

En Chile, España y Suiza la ley contiene extensa reglamentación sobre la emisión de obligaciones o papeles valores (Chile: ley $\mathrm{N}^{\circ} 4657$ de 25 de Setiembre 1924; España: arts. 111 a 132 de la ley; y Suiza: arts. 965 y 968).

Sólo en el Perú se hace una ligera refezencia a ellos en el Código de Comercio (arts. 21, 69, 534, 535 y 536) y se reglamenta la emisión de títulos al portador con los artículos 1802 y 1812 del Código Civil, siendo de advertir que en especial nuestro Código Civil reglamenta los bonos hipotecarios al portador sin ocuparse de los bonos con otra clase de garantía y que, en nuestro concepto, tiene el defecto de subordinar la emisión de bonos al portador al control del Banco Central Hipotecario del Perú. 


\section{Reglamentación de la responsabilidad}

De todo lo expuesto se desprende cómo las diversas legislaciones establecen los derechos $\mathrm{y}$ obligaciones de los accionistas y administradores ante la sociedad $\mathrm{y}$ ante terceros.

Ya sabemos que la ley chilena (art. 458) limita la responsabilidad de los administradores a la ejecución de su mandato; la española, en su artículo 80, reglamenta la acción de responsabilidad en los términos siguientes: "La acción de responsabiidad contra los administradores se entablark "por la Sociedad, previo acuerdo de la junta general, que puede ser adopta"do cunque no conste en el orden del día".

"En cualquier momento, la jurita general podró transigir o renunciar al "ejercicio de la acción, siempre que no se opusieran a ello socios que re"presenten al menos, la décima parte del capital social. El acuerdo de pro"mover la acción o de transigir implica la destitución de los Administrado"res.

"Los accionistas que representen la porción de capital que queda es"tablecida en el párrafo anterior podróm entablar conjuntamente contra los "Administradores la acción de responsabilidad, cuando la Sociedad no lo "hiciere, dentro del plazo de tres meses, contados desde la fecha del acuer"do o cuando éste hubiera sido contrario a la exigencia de responsabilidad.

"Los acreedores de la Sociedad sólo podrán dirigirse contra los Ad"ministradores cuando la acción tienda a reconstruir el patrimonio social, na "haya sido ejecutada por la sociedad o sus accionistas y se trate de un "acuerdo que amenace gravemente la garantía de los créditos".

El Código Suizo de Obligaciones, en cambio, contiene todo un título sobre la responsabilidad (arts. 752 al 761) en que reglamenta en detalle la responsabilidad de los accionistas y administradores en todos sus momentos haciendo mención de la responsabilidad de los cutores de los prospectos, de la que concieme a los fundadores, de la que toca a los administradores $y$ controladores, y de la que concierne a los liquidadoras. Establece la obligación de indemnizar daños y perjuicios fuera de cuiebra o en caso de quiebra, cómo se producirá la liberación de responsabilidad, cuóndo prescribirá $Y$ ante qué fuero se perseguiró, especificando cada uno de los casos de negligencia. o dolo en que se produce tal responsabilidad.

El Código nuestro, en el artículo 164, también hace responsables a las administradores por la infracción de las leyes y estatutos, pero sin contener reglamentación.

Consideramos que la ley suiza es un modelo a este respecto $y$ que sus principios deberían ser adoptados. 


\section{CONCLUSION}

Del estudio que ontecede se ciesprende:

1. Que las reglas de nuestro Código de Comercio en cuanto conciernen a las sociedades anónimas son extremadamente deficientes.

2. Que se caracterizan por abandonar a la voluntad de los interesados la solución de la mayor parte de los problemas que estas instituciones originon.

3. Que esta voluntad por ser casi siempre la de los fundadores o mayores accionistas da lugar a frecuentes abusos.

4. Que por falta de medidas de garantía y de vigilancia deja desamparadas a las minorías y muchas veces a los acreedores y terceros.

5. Que es, por lo mismo, urgente una nueva ley de sociedades anónimas en el Perú.

6.-Que el control de las sociedades anónimas por medio de una Superintendencia no es aconsejable, por cuanto retarda su vida, maniata sus actividades, las burocratiza y no impide a la larga los males que se trata de evitar; creando otros de no menor importancia.

7. Que el control por medio de la reglamentación legal, esto es el régimen de libertad para actuar dentro de los cauces del derecho, es el mejor, pues en él cada accionista se convierte en un vigilante y nadie mejor que él puede defender sus propios derechos y sus intereses.

8. Que las legislaciones de España y Suiza constituyen a este respecto perfectos modelos dignos de inspirar cualquier reforma de la legislación nacional.

9. Que en la legislación de Chile se encuentra, igualmente, importantes principios que podrían ser adoptados.

10. Que nuestra legislación, al reglamentar las sociedades anóminas debería:

A) Reconocer la unidad fundcrmental del derecho comercial y el civil; y que las sociedades anónimas, cualquiera que sea su naturaleza (agrícolas, comerciales o mineras) deben someterse $\alpha$ una sola legislación.

B) Permitir que los fines de la sociedad anónima se establezcan con amplia libertad, sean o no económicas, mientras se respete las leyes, el orden público y las buenas costumbres. tianos.

C) Inspirarse en una orientación social acorde con los principios cris-

D) Regular detalladamente la institución a fin de evitar los conflictos que ahora se producen o pueden producirse, en forma tal que el control de las sociedades anónimas se produzca por virtud de la ley y el debido ejarcicio de los derechos de los accionisias y no mediante la crección de organismos estatales que entraben su movimiento c las burocraticen.

E) Definir las características esenciales de que deben gozar las sociedades anónimas, como son: su personalidad, limitación de responsabilidad, 
división del capital en acciones o porciones, posibilidad de transferir las accio. nes con mayor o menor liberiad, denominación y fin.

F) Rodear al acto de fundación de la sociedad de todas las garantías: que las leyes modernas consideran necesarias, especialmente en materia de responsabilidad de los promotores y valuación de los aportes.

G) Establecer los derechos esenciales de los accionistas a ser recona cidos como socios; a transferir sus acciones; a convocar a las juntas; a concurrir a ellas $y$ votar; $\alpha$ elegir administradores; $\alpha$ examinar las cuentas $y$ solictiar informes sobre la marcha de la institución; a percibir dividendos; a participar en el producto de la liciuidación cuando fenezca la sociedad: a participar en las nuevas emisiones de acciones; a gozar de las preferen. cias que les correspondan; y a impugnar los actos $\mathrm{y}$ acuerdos indebidos..

H) Señalar los límites de tales derechos.

I) Reconocer las garantías que debe darse a las mayorías, especialmente para que la sociedad sea gobernada por ellos, estableciendo al efecto la forma cómo deben ser computadas y la necesidad de respetar sus acuerdos lícitos.

J) Proclamar las garantías que corresponden a las minorías, especialmente sus derechos esenciales de convocar a las juntas, cuando no lo hagan. los administradores; de que haya un límite mínimo para el quorum, las vo. taciones $\mathrm{Y}$ cicuerdos en los cazos mós importantes; $y$ de impugnar los actos indebidos de los administradores o de las mayorías.

K) Garantizar el debido funcionamiento de las asambleas de accionistas (citaciones, derecho de concurrir $\mathrm{y}$ votar).

L) Esclarecer cómo se compulará el quorum cuando las acciones no representadas sean al potrador.

LL) Señalar los derechos, obligaciones y responsabilidad de los ad. ministradores, inclusive la duración y revocabilidad de su mandato y el modo. de nombrarlos, la forma de designar comisiones ejecutivas en que estén re. presentadas las mayorías y las minorías, las limitaciones a sus remuneraciones y los casos de incompatibilidad para el ejercicio de determinados cargos.

M) Prescribir el modo de confeccionar, presentar y dar publicidad a: los balances y la posibilidad de hacerlos examinar, junto con los documen. tos comprobatorios, por auditores, comisarios o inspectores de cuentas.

N) Determinar el modo de conservar la continuidad de la administración y un control económico permanente.

Ñ) Garantizar la obligación de pagar o el derecho de percibir dividendos cuando las utilidades sociales los justifiquen. alterados.

O) Asegurar el cumplimiento de los fines sociales y que éstos no sean

P) Dar garantías para la buena liquidación de la sociedad.

Q) Resguardar los derechos de los acreedores.

R) Señalar las reglas a que se sujetará la emisión de bonos y obligaciones de toda clase. 